Article

\title{
A Comprehensive Appraisal of the Wild Food Plants and Food System of Tribal Cultures in the Hindu Kush Mountain Range; a Way Forward for Balancing Human Nutrition and Food Security ${ }^{\dagger}$
}

\author{
Abdullah Abdullah ${ }^{1}$, Shujaul Mulk Khan ${ }^{1,2, *}$, Andrea Pieroni ${ }^{3,4} \mathbb{D}^{\mathbb{D}}$, Aminul Haq ${ }^{5,6} \mathbb{D}^{\text {, Zahoor U1 Haq }}{ }^{1,7}$, \\ Zeeshan Ahmad ${ }^{1}$, Shazia Sakhi ${ }^{8}$, Abeer Hashem ${ }^{9,10}$, Al-Bandari Fahad Al-Arjani ${ }^{9}$, Abdulaziz A. Alqarawi ${ }^{11}$ \\ and Elsayed Fathi Abd_Allah ${ }^{11}$ (D)
}

check for updates

Citation: Abdullah, A.; Khan, S.M.; Pieroni, A.; Haq, A.; Haq, Z.U.; Ahmad, Z.; Sakhi, S.; Hashem, A.; Al-Arjani, A.-B.F.; Alqarawi, A.A.; et al. A Comprehensive Appraisal of the Wild Food Plants and Food System of Tribal Cultures in the Hindu Kush Mountain Range; a Way Forward for Balancing Human Nutrition and Food Security. Sustainability 2021, 13, 5258. https:// doi.org/10.3390/su13095258

Academic Editor: António Raposo

Received: 17 March 2021

Accepted: 27 April 2021

Published: 8 May 2021

Publisher's Note: MDPI stays neutral with regard to jurisdictional claims in published maps and institutional affiliations.

Copyright: (c) 2021 by the authors. Licensee MDPI, Basel, Switzerland. This article is an open access article distributed under the terms and conditions of the Creative Commons Attribution (CC BY) license (https:/ / creativecommons.org/licenses/by/ $4.0 /)$.
1 Department of Plant Sciences, Quaid-i-Azam University, Islamabad 45320, Pakistan; abdullahkhan@bs.qau.edu.pk (A.A.); zahoornaturalist@gmail.com (Z.U.H.); zeeshanahmad78@ymail.com (Z.A.)

2 Pakistan Academy of Sciences, Islamabad 45320, Pakistan

3 University of Gastronomic Sciences Pollenzo, Piazza V. Emanuele II, I-12042 Bra/Pollenzo, Italy; a.pieroni@unisg.it

4 Department of Medical Analysis, Tishk International University, Erbil 44001, Kurdistan, Iraq

5 Department of Botany, University of Peshawar, Peshawar 25130, Pakistan; aminulhaq_bot@yahoo.com

6 Department of Botany, GPGC Khar Bajaur 18650, Pakistan

7 Department of Botany, SBBU Sharingal Warai campus Dir, Sheringal 18200, Pakistan

8 Center for Plant Sciences and Biodiversity, University of Swat, Mingora 19130, Pakistan; shaziasakhi@hotmail.com

9 Botany and Microbiology Department, College of Science, King Saud University, Riyadh 11451, Saudi Arabia; habeer@ksu.edu.sa (A.H.); aalarjani@ksu.edu.sa (A.-B.F.A.-A.)

10 Mycology and Plant Disease Survey Department, Plant Pathology Research Institute, ARC, Giza 12511, Egypt

11 Plant Production Department, College of Food and Agricultural Sciences, King Saud University, Riyadh 11451, Saudi Arabia; alqarawi@ksu.edu.sa (A.A.A.); eabdallah@ksu.edu.sa (E.F.A.)

* Correspondence: smkhan@qau.edu.pk

$+\quad$ This article is dedicated to the memory of Habib Ahmad (TI), Emeritus of Hazara University, Pakistan \& Fellow of the Pakistan Academy of Sciences who passed away on 7 April 2021; Habib was an extraordinary scholar and great human being and he has represented an irreplaceable academic guide for generations of young botanists, plant ecologists, and agricultural scientists across the globe.

Abstract: The tribal belt of the Hindu Kush mountains is famous for its unique culture, ethnography, wild food plants, food systems, and traditional knowledge. People in this region gather wild plants and plant parts using them directly or in traditional cuisine, or sell them in local markets. However, there is a huge lack of documentation of the food system, particularly that related to wild food plants (WFP). In the current study, we focus on the uses and contributions of WFPs in the traditional tribal food system of the Hindu Kush valleys along the Pakistan-Afghanistan border. Ethnobotanical data were gathered through questionnaire surveys of 84 informants, including 69 men and 15 women, belonging to 21 different villages of the chosen area. In tribal societies men and women rarely mix and thus very few women took part in the surveys. We documented 63 WFP species belonging to 34 botanical families, of which 27 were used as vegetables, 24 as fruits, six in different kinds of chutneys (starters), and six as fresh food species. Fruits were the most used part (41\%), followed by leaves $(24 \%)$, aerial parts $(24 \%)$, seeds $(7 \%)$, stems $(3 \%)$, and young inflorescences $(1 \%)$. The reported uses of Carthamus oxyacantha, Pinus roxburghii seeds, and Marsilea quadrifolia leaves are novel for the gastronomy of Pakistan. The results reveal that WFPs provide a significant contribution to local food systems and play a role in addressing human nutritional needs, which are usually not met through farming practices. The tribal peoples of the Hindu Kush use WFPs for their nutritional value, but also as a cultural practice-an inseparable component of the tribal community's lifestyle. This important traditional knowledge about the gathering and consumption of WFPs, however, is eroding at an alarming rate among younger generations due to the introduction of fast-food, modernization, and globalization. Therefore, appropriate strategies are imperative not only to safeguard traditional 
plants and food knowledge and practices, as well as the cultural heritage attached to them, but also to foster food security and thus public healthcare via local wild foods in the region.

Keywords: gastronomy; livelihood; public healthcare; traditional knowledge; wild food plants; valleys of the Hindu Kush mountain range

\section{Introduction}

Wild food plants (WFP) have played a crucial role in food systems since the beginning of human civilization [1]. Wild food plants refer to the non-cultivated plant species that are gathered or harvested by local communities from their surrounding ecosystems for utilization in their food systems [2]. Ecosystems in the tribal belt are diverse, being composed of plains, forests, and pastures, providing habitat to various kinds of wild fruits and vegetables [3]. Not only are these WFPs important from a nutritional point of view, but they have important medicinal value [4-7]; various WFPs have been evaluated for their pharmacological properties in many other parts of the world $[5,8,9]$. Recently, a number of WFPs have been identified as "functional foods" due to their nutritional value. They provide a healthy diet and can contribute to the prevention of some illnesses [10,11]. According to researchers, most WFPs are a rich source of bioactive compounds, such as essential fatty acids, vitamins, and complex sugars [11-13], and can contribute significantly to the alleviation of malnutrition [3]. Their importance in income generation, poverty reduction, nutritional balance, food security, and agricultural diversification has been emphasized in several studies [14,15]. One of the major contributions of WFPs is their use in food security by providing alternative food sources and food diversity in traditional communities [16]. Wild food plants play a crucial role in human survival during times of famine [17] and food shortages; recent examples include their use during the COVID-19 pandemic crisis, and the geopolitical and tribal unrest around the world.

Very few studies have been conducted to document food plants in Pakistan and the area under consideration in this article has never been studied before. Such comparisons are imperative as the Hindu Kush receives less summer precipitation than the Himalayas which gives rise to different kinds of WFPs.

Pakistan is a lower-middle-income country and the 6th most populous in the world [18]. It experiences all four seasons and has a wide diversity of natural resources, especially plants [19], and it still ranks as the 11th most food insecure country in the world [20]. About $60 \%$ of the people in the country are food insecure [18]. Food insecurity increases in the tribal belt of the country due to conflicts, distance from cities, and the prevailing dry climate. The Pakistani-Afghan border in the Hindu Kush mountain range has always been the center of tension due to its geopolitical position. Man-made catastrophes, the dramatic increase in the human population, limited access to food, and local livelihood strategies are the other major reasons for food insecurity and poverty in the tribal belt [21]. Wild food plants are an important resource for poor local communities and can be of tremendous help in alleviating hunger and malnutrition if properly managed and utilized. To date, little research has been conducted on the wild vegetable and fruit species used in the food systems of Pakistan in general and Pakistani-Afghan border regions in the Hindu Kush mountain range in particular [16,19,22-28]. The book by Abbasi et al. [29] on the ethnobotanical and nutraceutical aspects of the wild edible vegetables of the Lesser Himalayas is one of the major contributions in this regard.

\section{Tribal Culture}

The people of the region practice and enjoy a centuries-old culture known as Pashtunwali or Pukhtunwali. Pashtunwali is a very common cultural heritage of the tribal communities of Pathans living along the Pakistani-Afghan border in the Hindu Kush mountain range. It is a way of life or legal social code of conduct that governs their lives. 
According to [30] it is a 2000-3000 years old tradition that remains the central pillar of tribal societies. In this era of modernization, Pashtunwali is perceived as culturally idiosyncratic, significantly influencing perceptions, behaviors, and thoughts in everyday life [31,32]. Code of honor (Nang), hospitality (Melmastia), and revenge (Badal) are the three core pillars of Pashtunwali [33]. The code of honor, or self-respect and dignity, is a key component and characteristic of Pashtun society. Melmastia is a sum of conventions and an immediate reward from local societies regarding local cultural values, while Badal is like a debt which ends with revenge. These three cultural customs are the sum of tribal communal expectations from members of their society, as well as from outsiders [34]. These customs are related to WFPs in that Pathans offer food to each other and safeguard their natural resources. Although the tribal societies living along the Pak-Afghan border in the Hindu Kush mountain range are well known for their unique traditional food system, it has not been explored by researchers to document the valuable traditional knowledge about WFPs. The Bajaur area is the most populous, climatically varied, and ethnographically rich in the tribal belt of the Hindu Kush mountain range and it exemplifies the culture and traditional knowledge of the entire Pak-Afghan border and thus it was selected for the current study. It is a region composed of relatively dry valleys in the Hindu Kush mountain range. As for the food system in the tribal belt, especially in the area under investigation, it is worth mentioning that people are financially poor and most of the time they use WFPs. They eat at home most of the time, and the practice of hoteling and eating out in restaurants or other food points is uncommon. All of this strengthens the ties between people and wild food resources, including plants. Climate is one of the main drivers affecting all facets of life including wild food and food systems, with considerable variation in the different administrative units (tehsil) of the study area, i.e., Barang in the south, Nawagai and Chamrkand in the southwest, and Mamund, Salarzai, and Utmankhel tehsils in the north and northeast. Local communities collect wild vegetables and fruits from side valleys, mountains, and cultivated fields. They know the best and most suitable gathering seasons of wild vegetables using traditional ecological knowledge (TEK). The proper time and method of collecting various WFPs is crucial in terms of nutritional value. Women usually cook them in traditional tribal styles. The demand for wild vegetables and fruits increases in different seasons when cultivated fruits and vegetables are not available. Bearing in mind the importance of WFPs in the food system of tribal communities, the current study was designed to (1) document the diversity of WFPs gathered and consumed by tribal communities; (2) assess traditional knowledge about WFPs, their role and contribution in nutrition and the traditional tribal food system; and (3) compare the Hindu Kush valleys with other areas in regard to wild food plants.

\section{Methodology}

\subsection{Study Area}

The study region is a tribal area that remained part of the Federally Administered Tribal Areas (FATA) up to 2018. The tribal areas of Pakistan form a long narrow belt along the historical Durand Line (Pakistani-Afghan border). Federally Administered Tribal Areas consisted of six frontier regions (FR), i.e., Kohat, Bannu, Tank, Dera Ismail Khan, Peshawar, and Lakki Marwat, and seven agencies, namely Bajaur, Mohmand, Khyber, Orakzai, Kurram, North Waziristan, and South Waziristan. According to certain writers [35], in the mid-19th century the British faced difficulties and challenges in tax collection and effective control over the tribal belt and, thus, devised a legal and administrative system known as the Criminal Tribes Act of 1871. The law was "designed for the registration, surveillance, and control of certain tribes" [36] that was later enacted under the frontier crimes regulation (FCR). This remained in effect in the tribal belt until 2018. In that year, the government of Pakistan merged the whole tribal belt of FATA into the mainstream province of Khyber Pakhtunkhwa in the hope of promoting harmony and development following the drafting of the constitution of Pakistan. The area selected for the current study is a mountainous territory, with an area of $1296 \mathrm{~km}^{2}$, situated in northwestern Pakistan, located at $34-51^{\circ} \mathrm{N}$ 
latitude and 71-31 $\mathrm{E}$ longitude [37]. It shares a 52-km-long border with Afghanistan west of the Panjkora River, possessing three important passes, i.e., Nawa Pass, Ghakhi Pass, and Letaisar [38]. These three passes play a significant role in trade and the sharing of traditional knowledge between both countries. The research area is mainly inhabited by the Utmankhel and Tarkanri tribes, which speak different dialects of Pashto. The Utmankhel tribe resides in the southeast, bordering the districts of Malakand, while the Tarkanri tribe lives in the northwest on the Pakistani-Afghan border of the Hindu Kush mountains. The Utmankhel tribe is divided into the sub-tribes of Alizai, Shamozai, Aseel, Gharshamozai, and Mandal [39]. The Tarkanri tribe comprises the sub-tribes Mamund, Salarzai, Safi, Khalji, and other sub-ethnic groups who live in the former state of Khar [40]. According to Sher 2019, [40], the Utmankhels are descendants of the Kirlan tribe of Waziristan who migrated to the valleys of Arang and Barang in Bajaur during the 12th century. On the other hand, the Tarkanri people are descendants of Afghani Pashtuns. Before the events of 11 September 2001, people of both areas used to visit the two countries easily for various purposes. In short, Afghan culture has had a great impact on the Tarkanri people. Most of the people of the district live in rural parts of the area (Figure 1).

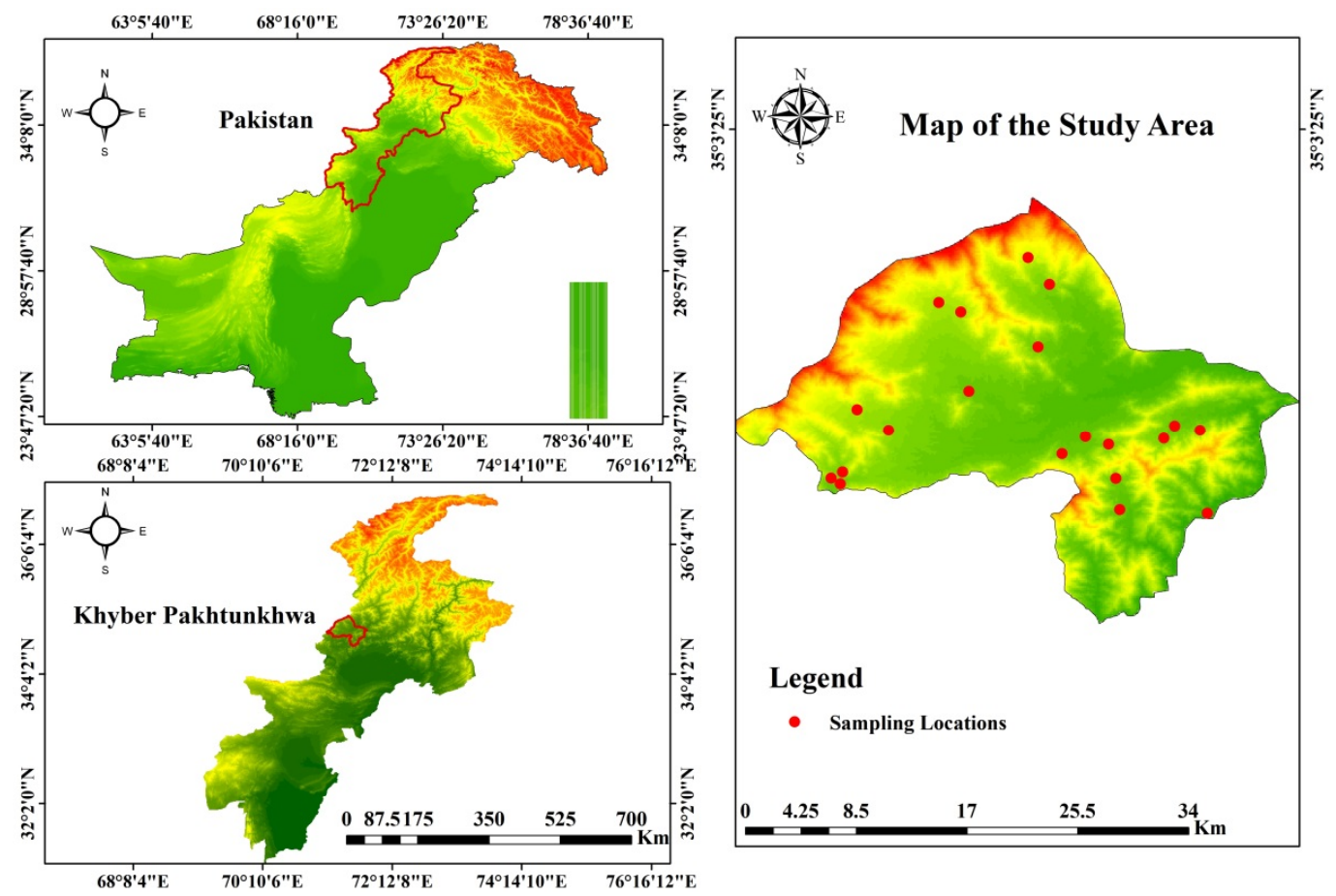

Figure 1. Map of the study area, showing the 21 studied villages.

The district has many natural resources, such as different kinds of stones, including marble, and other minerals. Local communities are involved in the extraction of marble, limestone, manganese, chromites, and talc, among other mineral resources. Geographically, the study area lies at the end of the Hindu Kush mountain range which creates considerable disparity and uncertainty in the pattern of monsoon rains from year to year. The climate of the district varies from extremely hot to bitter cold while traveling from the southeast to the northwest. The weather remains pleasant for most of the summer, but the temperature drops below freezing during winter. The area receives about $800 \mathrm{~mm}$ of annual rainfall. Variation in the climatic conditions of the area leads to a considerable diversity of plants and, thus, WFPs [38]. The people are mostly farmers, and a few others are teachers, drivers, cobblers, and businessmen. A considerable number of local people work in other parts of the country or abroad and depend on remittances for their livelihood. The local people have been collecting WFPs for nutritional and ethnomedicinal purposes for countless generations [41,42]. 


\subsection{Data Collection}

In the current study, 21 different villages were selected for interviews and gathering data on WFPs using a random table method where 3 villages from each of the tehsils (administrative units) of the study area were selected for questionnaire data collection (Table 1). Two visits to each village were arranged for this purpose between March and November 2016. Interviews were conducted following the code of ethics of both the International Society of Ethnobiology and the American Anthropological Association [42]. Knowledgeable informants were selected through the snowball sampling method [43-45]. A total of 84 informants were interviewed (four from each village) including 69 men and 15 women. The age of the informants ranged from 17 to 85 years, while education level ranged between illiterate to university degree (Table 2). The interviews were conducted in the Pashto language. Participants were asked about the local names, parts used, collection times, recipes and modes of utilization, uses in other dishes, and the sale or marketing of the WFPs species they gathered in the past and still gather today [45]. The first author comes from the study area and has family ties with a few of the villages studied, which helped considerably in gathering data about the uses of WFPs and selecting the informants. Each interviewee was verbally informed that the data gathered would be published and shared globally, which could help them by garnering international interest in their traditional knowledge and use of food plants, as well as the plants they associate with.

Table 1. The geographical position of the 21 studied villages in the seven tehsils of the study area.

\begin{tabular}{|c|c|c|c|c|c|c|c|}
\hline S No & Tehsil Name & Population & Tribes & Studied Villages & $\begin{array}{c}\text { Latitude } \mathrm{N} \\
\circ,{ }^{\prime},{ }^{\prime \prime}\end{array}$ & $\begin{array}{c}\text { Longitude } \\
\circ, 1,11\end{array}$ & Altitude (Meters) \\
\hline \multirow{3}{*}{1} & \multirow{3}{*}{ Utmankhel } & \multirow{3}{*}{107,356} & \multirow{3}{*}{ Shamozai } & Arang Bagh & $344249.42 \mathrm{~N}$ & $713913.01 \mathrm{E}$ & 1005 \\
\hline & & & & Taoheed Abad & $344321.73 \mathrm{~N}$ & $714138.56 \mathrm{E}$ & 1156 \\
\hline & & & & Ghazi Baba & $344339.08 \mathrm{~N}$ & $713957.31 \mathrm{E}$ & 941 \\
\hline \multirow{3}{*}{2} & \multirow{3}{*}{ Barang } & \multirow{3}{*}{76,558} & \multirow{3}{*}{ Aseel } & Kamal Dara & $343802.82 \mathrm{~N}$ & $713617.07 \mathrm{E}$ & 906 \\
\hline & & & & Nazar Mina & $344007.65 \mathrm{~N}$ & $713602.20 \mathrm{E}$ & 1013 \\
\hline & & & & Targhao & $343747.60 \mathrm{~N}$ & 7142 07. $79 \mathrm{E}$ & 688 \\
\hline \multirow{3}{*}{3} & \multirow{3}{*}{ Khar } & \multirow{3}{*}{247,510} & \multirow{3}{*}{$\begin{array}{c}\text { Alizai, } \\
\text { Mamund and } \\
\text { Salarzai }\end{array}$} & Batai & $344223.92 \mathrm{~N}$ & $713532.97 \mathrm{E}$ & 994 \\
\hline & & & & Shinkey & $344256.00 \mathrm{~N}$ & $713400.74 \mathrm{E}$ & 931 \\
\hline & & & & Sara Mena & $344146.70 \mathrm{~N}$ & $713226.70 \mathrm{E}$ & 963 \\
\hline \multirow{3}{*}{4} & \multirow{3}{*}{ Salarzai } & \multirow{3}{*}{268,517} & \multirow{3}{*}{$\begin{array}{l}\text { Salarzai and } \\
\text { Mashwani }\end{array}$} & Dara & $344855.51 \mathrm{~N}$ & $713050.10 \mathrm{E}$ & 964 \\
\hline & & & & Gabar Cheena & $345452.93 \mathrm{~N}$ & $713010.15 \mathrm{E}$ & 1276 \\
\hline & & & & Tofann Shah & $345305.17 \mathrm{~N}$ & $713136.50 \mathrm{E}$ & 993 \\
\hline \multirow{3}{*}{5} & \multirow{3}{*}{ Chamarkand } & \multirow{3}{*}{2868} & \multirow{3}{*}{$\begin{array}{c}\text { Sahibzadgan, } \\
\text { Molyan }\end{array}$} & Karkani & $344445.15 \mathrm{~N}$ & $711846.86 \mathrm{E}$ & 1161 \\
\hline & & & & Kotkai & $344321.57 \mathrm{~N}$ & $712053.18 \mathrm{E}$ & 1060 \\
\hline & & & & Lar Chamarkand & $344112.54 \mathrm{~N}$ & $711245.37 \mathrm{E}$ & 1057 \\
\hline \multirow{3}{*}{6} & \multirow{3}{*}{ Nawagai } & \multirow{3}{*}{79,002} & \multirow{3}{*}{$\begin{array}{l}\text { Safee and } \\
\text { Miangan }\end{array}$} & Nawagai & $344007.88 \mathrm{~N}$ & $711702.82 \mathrm{E}$ & 959 \\
\hline & & & & Sro Gato Miagan & $344032.89 \mathrm{~N}$ & $711748.55 \mathrm{E}$ & 1004 \\
\hline & & & & Khanano Kalay & $343945.39 \mathrm{~N}$ & $711739.80 \mathrm{E}$ & 1032 \\
\hline \multirow{3}{*}{7} & \multirow{3}{*}{ Mamund } & \multirow{3}{*}{311,873} & \multirow{3}{*}{$\begin{array}{c}\text { Mamund and } \\
\text { Wara } \\
\text { Mamund }\end{array}$} & Barkhalozo & $345114.67 \mathrm{~N}$ & $712541.36 \mathrm{E}$ & 1185 \\
\hline & & & & Umarey Mamund & $344558.62 \mathrm{~N}$ & $712613.95 \mathrm{E}$ & 955 \\
\hline & & & & Mena & $345152.66 \mathrm{~N}$ & $712413.47 \mathrm{E}$ & 959 \\
\hline
\end{tabular}


Table 2. Ages and literacy levels of the informants in the study area.

\begin{tabular}{ccc}
\hline & Literacy/Education Level of the Informants & \\
\hline Literacy level & No. of informants & Percentage \\
\hline Illiterate & 39 & 46.43 \\
\hline Primary & 21 & 25.00 \\
\hline Middle & 13 & 15.48 \\
\hline Secondary & 7 & 8.33 \\
\hline University & 4 & 4.76 \\
\hline & Nge Ranges of the Interviewees & \\
\hline Age group & Nof informants & Percentage \\
\hline $17-27$ & 7 & 8.33 \\
\hline $28-37$ & 9 & 10.71 \\
\hline $38-47$ & 16 & 19.05 \\
\hline $48-57$ & 15 & 17.86 \\
\hline $58-67$ & 13 & 15.48 \\
\hline $68-77$ & 15 & 17.86 \\
\hline $78-85$ & 9 & 10.71 \\
\hline & &
\end{tabular}

The interviewees were asked about the settlement they live in, as well as their age, place of birth, and occupation. They were also asked the following questions: (1) What wild vegetable species do you collect? (2) What wild fruit species do you collect and use? (3) What species do you use in sauces, salads, and chutneys (4) What WFPs do you use as raw foods (5) What wild herbal drinks do you consume? (6) What wild edible seeds do you collect and use? (7) Do you collect WFPs for marketing purposes? (8) How frequently do you use the plant in a season? (9) What are the names of WFPs in your language? (10) Which parts do you use? (11) What recipes you prepare? (12) What is the best season for collecting? (13) What traditional dishes are made with these WFPs? (14) Did you use any WFPs in the past which you did not mention previously? Thematic analysis was carried out on the basis of our interviews and observations. All the data based on these questions were arranged in tabulated form. After interviewing four people in each village, a short field excursion with the interviewees was arranged to collect all available WFPs.

Collected plant specimens were identified with the help of the Flora of Pakistan [46] and the Wild Plants of the Swat Valley [47], and then plants names were cross-checked against the Plant List database [48]. Plants uses were also compared with previous studies $[16,19,22-29,47]$.

Secondary data were also gathered by collecting and reading local as well as scientific literature about the local names, cuisines, and tribal food systems for finalizing the article in hand.

\subsection{Data Analysis}

Data on WFPs, i.e., botanical name, local name, plant family, used parts, growth habit, mode of utilization, marketing, use reports, relative frequency of citation, and previous literature that reported their use, were gathered via a questionnaire and literature survey.

\subsubsection{Relative Frequency of Citation (RFC)}

The data on wild food plants, collected during the questionnaire survey, were also analyzed qualitatively via the relative frequency of citation (RFC) to highlight the local significance of each WFP species in the region following [5,49]: 


$$
\mathrm{RFC}=\frac{\mathrm{FC}}{\mathrm{N}}(0<\mathrm{RFC}<1)
$$

where FC denotes the number of informants mentioning a specific WFP species, while $\mathrm{N}$ is the total number of informants interviewed during the survey.

\subsubsection{Classification of WFPs Based on Mode of Consumption}

All WFPs were grouped into different food categories on the basis of consumption mode following Thakur et al 2017 [3]. Those plant species cooked as food were categorized as vegetables, for example, Caralluma tuberculata, Malva neglecta, and Digera muricata. Species that were consumed without cooking were classified in the category of fruits dry or fresh, i.e., Ficus carica, Morus alba, and Celtis caucasica. Another category consisted of plants used, together with salt and spices, to make sauces, salads, and chutneys, for example, Mentha longifolia, Mentha royleana, and Zanthoxylum armatum. Salvia moorcraftiana, Saccharum bengalensis, and Silene conoidea were considered as raw food species, or those plants, other than fruits, whose parts were consumed raw without cooking.

\section{Results}

\subsection{Tribal Food System and WFPS}

Tribal people have a unique and simple food system primarily based on WFPs, dairy products, and cereal crops they cultivate in their fields. Almost every family in the study area raises domesticated animals (sheep, goat, cow, or buffalo) to meet their dairy requirements [50]. They customarily collect WFPs while grazing their animals. They usually have a piece of land where they cultivate local vegetables and crops. They prepare and consume various kinds of cultural foods from these three abovementioned sources. Some of the well-known simple foods of this tribal region include Jawaro Neeny (roasted corn seeds), Ghanamo Neeny (wheat grains are roasted and then a little brown sugar is added to form small balls), Dhal (ground wheat grains are boiled with brown sugar and butter oil), Gongrhi (boiled wheat grains), Shedano rotay (wheat flour is mixed with cow oil and Carthamus oxyacantha seeds to make a bread that is baked in a tandoor), and Kakori (wheat flour is mixed with peanuts, resin, walnuts, coconut, and sugar to make a special type of bread). Kakori is prepared mostly when an infant start walking for the first time. Ghunzakhi (wheat flour mixed with vegetable oil, sugar, and Cuminum cyminm seeds) is a special type of sweet prepared and gifted mostly by women when they move from their mother's house to their in-law's house. Elderly individuals cook lentils and pulses in a unique traditional style: when the dish is prepared a cup or more of butter oil is added. This dish is offered at special cultural gatherings and ceremonies, such as Ashar. Ashar is a centuries-old tradition of the Pathans in which members of a local community gather to help each other in their work without consideration of compensation, monetary or otherwise. Unfortunately, today, this important cultural tradition is on the verge of extinction due to urbanization, modernization, and globalization. These traditional foods are considered an important feature and significantly contribute to the tribal food system. Tribal people of the study area living in valleys and the foothills collect WFPs to fulfill their food requirements. They are wholly or partially dependent on WFPs resources.

\subsection{WFPs and Their Taxonomic Categorization}

Overall, 63 folk taxa belonging to 34 botanical families were recorded. A high proportion of these WFPs belong to the Amaranthaceae and Leguminosae families (five species each), followed by Rhamnaceae, Rosaceae, Lamiaceae, and Polygonaceae (four species each), and then Brassicaceae and Moraceae (three species each). The most dominant WFP categories included vegetables ( 27 species), fruits ( 24 species), chutneys and sauces (7 species), and raw food species (six species). Field observations showed that the vegetable category was mainly composed of weeds locally called Gayyah (unwanted plant species 
occurring in or along crop fields). The traditional communities gathered these species for their own food uses, as well as that of their animals.

\subsection{Traditional Knowledge Related to Gathering WFPs}

Wild food plants were reported to be gathered from diverse localities, including agricultural fields, foothills, and forests. The diversity and availability of plants vary with seasonal changes. Local people possess traditional knowledge regarding the seasonal availability and time of collection of WFPs [51]. Spring (March-May) and Summer (JuneOctober) are the peak seasons for WFPs collection in the study region. Most WFPs are not available from November to February due to the cold temperatures [24]. Leaves and pot herbs grow well in April and August, while the best time for fruits ranges from June to October. Different vegetable species remain available for 2 to 9 months, whereas certain fruit species, such as Sideroxylon mascatense, Punica granatum, Vitis jacquamontiana, Morrus, as well as Ficus and Zizphus species, are only available for a few months.

\subsection{Shepherds and Their Role in Gathering WFPs}

Shepherd communities, in search of grasses and fodder for their cattle, migrate from one region to another in a cyclic manner. They graze their sheep, goats, and cows on hills and in the mountains and collect WFPs for their own dietary needs. They are totally or partially dependent on WFPs and homemade dairy products.

One elderly participant (81-year-old man) belonging to the Utmankhel - Alizai tribe mentioned his view about the role of WFPs in the food system of shepherds and grass collectors in these words: "In our time, when we used to visit the mountains for cattle grazing or grass and fuelwood collection, and we felt hungry, we ate mint (Mentha longifolia) and heart wing sorrel (Rumex hastatus) leaves with green chilies, onions, tomatoes, and prickly ash (Zanthoxylum armatum) seeds with wheat or barley bread. We ground these on big rocks with the help of small round stones along streams or springs. We used the creeping wood sorrel (Oxalis corniculate) as an alternative to Rumex hastatus leaves sometimes. Some people used to eat brown sugar with wheat or barley bread". Today, this practice of eating WFPs has decreased due to the modernization, globalization, and urbanization of communities.

\subsection{WFPs and Their Uses in Traditional Cuisine}

Our findings show that fruits were the most commonly used parts (41\%) of WFPs, followed by leaves $(24 \%)$, aerial parts $(24 \%)$, seeds $(4 \%)$, stems ( $3 \%)$, and young inflorescences $(2 \%)$, (Figure 2). The use of various parts varied from species to species and area to area within the region. Leaves and aerial parts were mostly used as vegetables, in sauces, or consumed raw, while fruits were mostly eaten raw. In terms of growth habit, the recorded WFPs were categorized as $57 \%$ herb, $22 \%$ tree, $19 \%$ shrub, and $2 \%$ climber species.

\subsubsection{Vegetable Species}

During the questionnaire survey, local people were asked (1) what wild vegetable species they collect? In response to our question, interviewees mentioned 27 species used as vegetables in the studied villages. According to the use reports, the most cited and used vegetable species were Nasturtium officinale (47), Oxalis corniculata (44), Trifolium repense (44), Solanum villosum (37), Digera muricata (31), Portulaca quadrifida (29), Malva neglecta (28), Vicia sativa (27), Cichorium intybus (21), and Caralluma tuberculata (19). Nasturtium officinale, locally called Termera, was the most used vegetable species in the region and considered a digestive. The species was collected by local communities beside water bodies such as streams, springs, ponds, and lakes from March to November. It was favored for its unique taste and availability. Oxalis corniculata was the most readily available species, which grows in the shade of other plants or humid places from March to December. Its widespread availability, long growing season, and special taste made it one of the most consumed vegetable species. Trifolium repense is a semi-domesticated species that grows alongside 
water bodies. It was widely consumed as a vegetable throughout the region. For example, Chokanr, or Trifolium repense leaves with rice, was a very popular traditional dish across the whole tribal belt. Solanum villosum, Solanum americanum, Descurainia sophia, and Sisymbrium irio leaves and young shoots were boiled in concentrated milk and offered to patients as well as older people as a digestive.

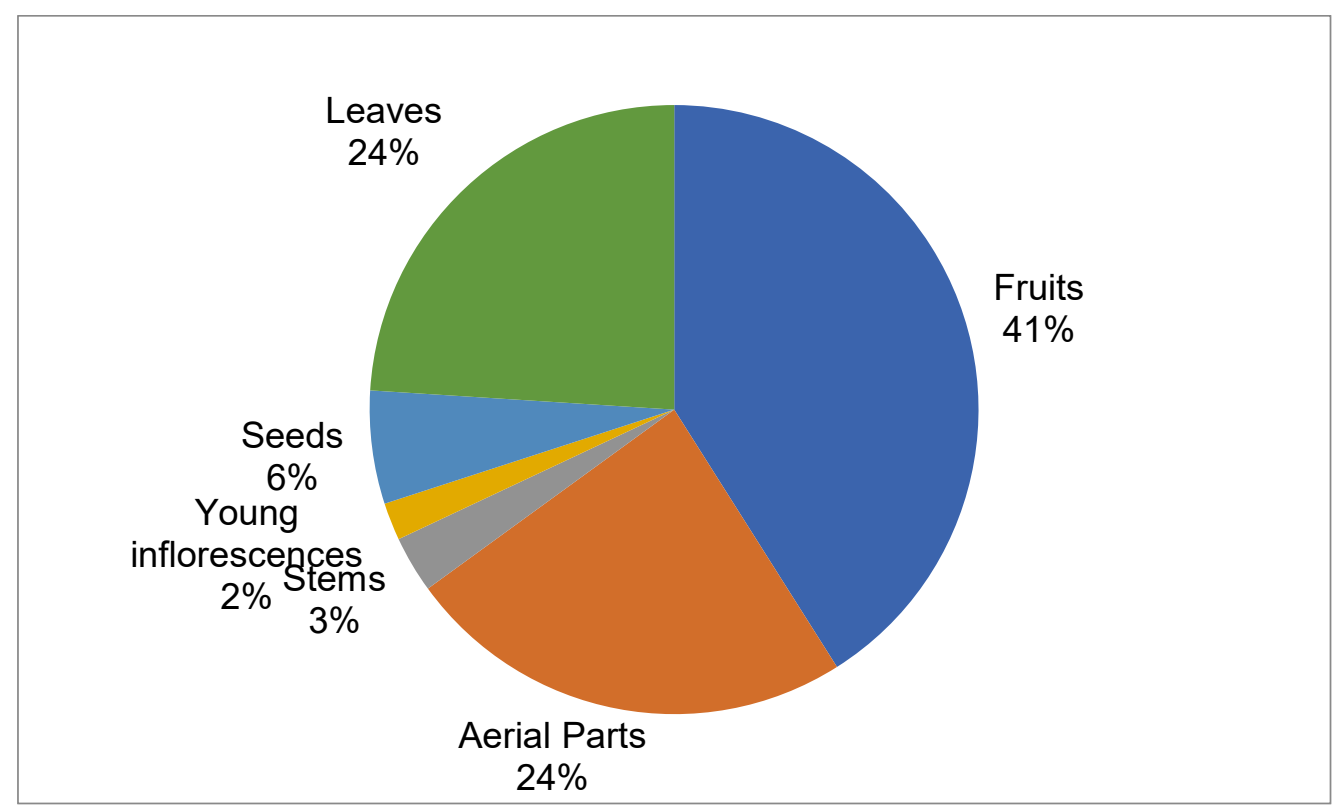

Figure 2. Contribution of the WFP's parts used in the tribal food system.

\subsubsection{Fruit Species}

In total, 24 species were collected from the wild and consumed raw by local inhabitants. According to the use reports, the most important wild fruit species were Ficus carica with 64 use reports, followed by Berberis lyceum (58), Myrtus communis (53), Olea ferruginea (48), and Sideroxylon mascatense (48). Ficus carica was a very common species in the study region and local people collected its fruits in the morning to avoid the hot weather, as it bears fruit during the hottest months of June and July. Berberis lyceum fruits were collected and mostly consumed raw, although some people also used the fruit to make a refreshing juice. Sideroxylon mascatense, which occurs in the low elevation hills, was another important fruit species of the study area. People collected ripe Sideroxylon fruits in large bottles or pots to maintain their shape and avoid bruising the fruit.

\subsubsection{Sauces and Chutneys}

In response to our questionnaire, informants reported only six species used in making chutney. The custom of herbal sauce or chutney making was not very common throughout the region but included the use of Mentha longifolia (40), Mentha royleana (34), Cuminum cyminum (21), Zanthoxylum armatum (37), Allium ampeloprasum (14), and Thymus linearis (7). Interestingly, all these species are aromatic and were used in fresh and dried forms as well. The local people shade-dried these species in their respective seasons for utilization throughout the year.

\subsubsection{Species Used Raw}

This category was also not common in the region. Fresh raw food species were collected from the wild and just masticated or chewed for their flavor or [52] to quench thirst or suppress appetite. Interviews confirmed only six plants, including the young shoots of Saccharum benghalensis (17), the fruits of Silene conoidea (22), the young shoots of Salvia moorcraftiana (9), and the aerial parts of Indigofera species (3), were consumed in the 
region. Additionally, the seeds of Carthamus oxyacantha and Pinus roxburghii were used as food.

\subsubsection{WFPs Used in Herbal Teas, Drinks, and Decoctions}

Myrtus communis, Mentha royleana, and Mentha longifolia were used in herbal teas and decoctions. Myrtus communis leaves were boiled with green tea and Mentha royleana or Mentha longifolia were used to prepare herbal drinks. These drinks were used to treat vomiting, diarrhea, heartburn, and other stomach-related problems. The local people kept it in dry form in their houses for off-season uses. Berberis lyceum, Punica granatum, and Morus nigra were used in fresh drinks. The juices of Berberis lyceum and Punica granatum were considered important drinks in the area. Indigenous people used these plants for cooling the body and quenching thirst. Berberis fruits have a very short period of availability and may be available in the market for only 20-30 days. On the other hand, Punica granatum fruits were stored by local communities. They stored it in grain bins and used it for a few months. Morus nigra is very common and produces large amounts of fruits, but its juice was not common in the study area. Very few informants reported its use as an herbal drink.

\subsection{Summary of WFP Cuisine}

Various recipes for cooking WFPs were recorded during the interviews with local informants. The traditional communities used WFPs in different ways, and the knowledge of these plants and their mode of consumption were passed down from their ancestors. There were different methods used for the preparation of wild foods depending on the nature of the plant. Wild vegetables, i.e., Amaranthus vridis, Amaranthus crispus, Chenopodium album, Rumex dentatus, Rumex histatus, Malva neglecta, Digera muricata, Nasturtium officinale, Lathyrus aphaca, Vicia sativa, Medicago polymaorpha, Medicago denticulata, Portulaca quadrifida, Cichorium intybus, Polygonum aviculare, Polygonum plebium, Solanum villosum, Solanum americanum, and Marsilea were cut into small pieces and boiled in water. After boiling these vegetables, onions were fried in oil, and then tomatoes and garlic were added [22]. After the addition of garlic, a special kind of sauce was made in the traditional tribal style, which is locally called Dagh or Tarka. Some people also added green chilies depending on preference and taste. Subsequently, the boiled vegetables were added and heated until the poured oil comes out on top of the dish. Some vegetables, such as Solanum villosum, Solanum americanum, Descurainia Sophia, and Sisymbrium irio, were boiled in concentrated milk [25]. Bitter vegetables like Caralluma tuberculata were cut into small pieces, boiled in water 2-3 times, and then fried in oil with onion, tomatoes, chilies, and condiments. Some people also cooked Caralluma with minced meat (Keema/Qeema).

\subsection{Storage and Uses of WFPs in the Off-Seasons}

The storage and drying of WFPs is an important practice that provides stability to the food system throughout the year [24]. In the study area, a number of plants, such as the aerial parts of Mentha longifolia, Mentha royleana, and Punica granatum fruits, were stored by local communities in dried form for consumption during the off-season. Our findings showed that in ancient times, local people used to store fruit of pomegranates in grain bins (which were made of mud), and then they used them during times of need. Morus alba, Sideroxylon mascatense, and Prunus armeniaca (Kakhta) fruits were dried and used in the winter season. In April, Allium carollianum leaves were collected by traditional communities to prepare local spices or masala in their homes. They shade-dried its leaves and then used the dried form with Curcuma longa (Korkaman), Cuminum cyminum, and Punica granatum seeds. The use of Punica granatum seeds in spices was a custom of the traditional communities. Myrtus communis leaves and fruits were stored in homes and used in lassi and herbal tea for their enticing aroma and appetizing flavor. 


\subsection{Relative Frequency of Citation}

In the present study, RFC values ranged from 0.01 to 0.8 . The highest RFC was recorded for Ficus carica (0.8), followed by Myrtus communis (0.7), Berberis lyceum (0.7), Nasturtium officinale (0.6), and Olea ferruginea (0.6) (Table 3). The high RFC values of certain wild fruit species demonstrate their abundant use and extensive knowledge among the tribal communities. Myrtus communis and Berberis lyceum have high RFC values but both species are facing conservation threats in the area. This continuous practice of gathering WFPs has caused an alarming decrease in the populations of some species. On the other hand, due to the cultural and religious importance of certain species, such as Ficus carica and Olea ferruginea, some plants are highly valued and thus distributed widely in the region. Therefore, on the basis of our field observations and interviews, we think that the extensive use of WFPs depends not only on the abundance of a species, but also on local preferences and its high nutraceutical value. However, traditionally people have used such food plants irrespective of their knowledge of the plant's impact on health. Rather than thinking about their health benefits, it has been more customary to use wild plants because of long-established traditions, but such uses are of tremendous benefit to these tribal people.

\subsection{Selling and Marketing of WFPs}

During the interviews, we asked the participants whether they collected or still collect WFPs for marketing purposes. In response, the interviewees reported 10 plant species that are available in the local markets of Bajaur, i.e., Khar, Pashat, Inayt Kalay, Nawagai, Memola, Chenagai, and Tawheed Abad. These 10 marketable species included four wild fruits, five vegetables, and one species used as a flavoring agent. The fruit species included Sideroxylon mascatense, Berberis lyceum, Ziziphus sativa, and Diospyrus lotus. Mentha longifolia, Mentha royleana, Caralluma tuberculata, Spinacia quadrifida, and Malva neglecta were the wild vegetables species, while Zanthoxylum armatum was used as a flavoring agent in various traditional dishes. All these species were available fresh in the market except Sideroxylon mascatense, whose fruits were available in the market in dried form and during the off-season as well (Table 3). 
Table 3. Wild food plants (WFP) gathered and consumed by traditional societies in the tribal belt of the Hindu Kush mountains.

\begin{tabular}{|c|c|c|c|c|c|c|c|c|c|c|c|c|}
\hline S. No & $\begin{array}{l}\text { Botanical } \\
\text { Name of } \\
\text { WFPs }\end{array}$ & $\begin{array}{l}\text { Local } \\
\text { Name of } \\
\text { WFPs }\end{array}$ & Family & HB & Part Used & $\begin{array}{l}\text { Recipes and Mode of } \\
\text { Utilization in Cuisines }\end{array}$ & $\begin{array}{l}\text { Contribution to } \\
\text { Tribal Food } \\
\text { System } \\
\text { (Use in Other } \\
\text { Cuisines) }\end{array}$ & Coll. Time & Marketing & UR & RFC & $\begin{array}{c}\text { Previously } \\
\text { Reported } \\
\text { in Pakistan for } \\
\text { Food Usages }\end{array}$ \\
\hline 1 & $\begin{array}{l}\text { Allium car- } \\
\text { olinianum } \\
\text { DC }\end{array}$ & Ogai & Amaryllidaceae & $\mathrm{H}$ & Leaves & $\begin{array}{l}\text { Leaves are used as a } \\
\text { salad or fried in oil with } \\
\text { tomato and } \\
\text { red chilies, and mixed } \\
\text { with different } \\
\text { ingredients in variety of } \\
\text { cousins }\end{array}$ & $\begin{array}{l}\text { i. Chicken Handi, ii. } \\
\text { Traditional bread } \\
\text { iii. Flavoring agent }\end{array}$ & Feb-Jun & + & 14 & 0.17 & \\
\hline 2 & $\begin{array}{l}\text { Amaranthus } \\
\text { crassipes } \\
\text { Schltdl. }\end{array}$ & Churlai & Amaranthaceae & $\mathrm{H}$ & Leaves & $\begin{array}{l}\text { Leaves are boiled in } \\
\text { water and then fried in } \\
\text { oil with tomato, onion, } \\
\text { and red chilies }\end{array}$ & $\begin{array}{l}\text { i. Indian squash } \\
\text { (Praecitrullus } \\
\text { fistulosus) }\end{array}$ & Apr-Dec & - & 8 & 0.10 & \\
\hline 3 & $\begin{array}{l}\text { Amaranthus } \\
\text { viridis L. }\end{array}$ & Ganar & Amaranthaceae & $\mathrm{H}$ & Leaves & $\begin{array}{l}\text { Leaves fried in oil with } \\
\text { tomato, onion, and red } \\
\text { chilies }\end{array}$ & $\begin{array}{c}\text { i. Pulses } \\
\text { ii. Indian squash }\end{array}$ & Apr-Dec & + & 23 & 0.27 & {$[22,23,25,26,28]$} \\
\hline 4 & $\begin{array}{l}\text { Asparagus } \\
\text { officinalis } \\
\text { L. }\end{array}$ & & Asparagaceae & $S$ & $\begin{array}{l}\text { Aerial } \\
\text { parts }\end{array}$ & $\begin{array}{l}\text { Leaves boiled in water } \\
\text { and then fried in oil with } \\
\text { tomato, onion, and red } \\
\text { chilies }\end{array}$ & - & Jun-Jul & + & 13 & 0.15 & \\
\hline 5 & $\begin{array}{l}\text { Berberis } \\
\text { lyceum } \\
\text { Royle }\end{array}$ & Koaray & Berberidaceae & $S$ & Fruit & Used fresh & i. Juices & Mar-Nov & + & 58 & 0.69 & {$[1,25,27]$} \\
\hline 6 & $\begin{array}{l}\text { Caralluma } \\
\text { tuberculata } \\
\text { N.E.Br. }\end{array}$ & Pamankay & Asclepediaceae & $\mathrm{H}$ & Stems & $\begin{array}{l}\text { Leaves fried in oil with } \\
\text { tomato, onion, and red } \\
\text { chilies }\end{array}$ & $\begin{array}{l}\text { i. Qeema } \\
\text { ii. Meat }\end{array}$ & Jun-Nov & - & 19 & 0.23 & {$[22-24,28]$} \\
\hline 7 & $\begin{array}{l}\text { Carthamus } \\
\text { oxyacantha } \\
\text { M.Bieb }\end{array}$ & Kareza & Asteraceae & $\mathrm{H}$ & Seeds & $\begin{array}{l}\text { Seeds are cooked in } \\
\text { bread and then the bread } \\
\text { is topped with butter oil }\end{array}$ & i. Caramelized candy & Jul-Sep & - & 13 & 0.15 & \\
\hline 8 & $\begin{array}{l}\text { Celtis } \\
\text { caucasica } \\
\text { Willd. }\end{array}$ & Tagh & Cannabaceae & $\mathrm{T}$ & Fruit & Taken as fruit & - & Mar-Jun & - & 27 & 0.32 & {$[24,26,27]$} \\
\hline
\end{tabular}


Table 3. Cont.

\begin{tabular}{|c|c|c|c|c|c|c|c|c|c|c|c|c|}
\hline S. No & $\begin{array}{l}\text { Botanical } \\
\text { Name of } \\
\text { WFPs }\end{array}$ & $\begin{array}{l}\text { Local } \\
\text { Name of } \\
\text { WFPs }\end{array}$ & Family & HB & Part Used & $\begin{array}{l}\text { Recipes and Mode of } \\
\text { Utilization in Cuisines }\end{array}$ & $\begin{array}{l}\text { Contribution to } \\
\text { Tribal Food } \\
\text { System } \\
\text { (Use in Other } \\
\text { Cuisines) }\end{array}$ & Coll. Time & Marketing & UR & RFC & $\begin{array}{l}\text { Previously } \\
\text { Reported } \\
\text { in Pakistan for } \\
\text { Food Usages }\end{array}$ \\
\hline 9 & $\begin{array}{l}\text { Chenopodium } \\
\text { album L. }\end{array}$ & Sarmay & Amaranthaceae & $\mathrm{H}$ & Leaves & $\begin{array}{l}\text { Leaves boiled in water } \\
\text { and then fried in oil with } \\
\text { tomato, onion, and red } \\
\text { chilies }\end{array}$ & $\begin{array}{l}\text { i. Pulses } \\
\text { ii. Yogurt }\end{array}$ & Mar-Jun & - & 11 & 0.13 & {$[19,22,24,25,28]$} \\
\hline 10 & $\begin{array}{l}\text { Cichorium } \\
\text { intybus L. }\end{array}$ & Kashni & Asteraceae & $\mathrm{H}$ & Leaves & $\begin{array}{l}\text { Leaves boiled in water } \\
\text { and then fried in oil with } \\
\text { tomato, onion, and red } \\
\text { chilies }\end{array}$ & $\begin{array}{l}\text { i. Pulses } \\
\text { ii. Rice }\end{array}$ & Apr-Jul & - & 21 & 0.25 & {$[23,25,28,29]$} \\
\hline 11 & $\begin{array}{l}\text { Cuminum } \\
\text { cyminumL. }\end{array}$ & Zeera & Apiaceae & $\mathrm{H}$ & Seeds & $\begin{array}{l}\text { Seeds used for aroma } \\
\text { and taste in various } \\
\text { traditional foods }\end{array}$ & $\begin{array}{l}\text { i. Meat } \\
\text { ii. Pulses } \\
\text { iii. Rice } \\
\text { iii. Custard } \\
\text { iv. Spices, } \\
\text { etc. }\end{array}$ & Apr-May & - & 19 & 0.23 & \\
\hline 12 & $\begin{array}{c}\text { Descurainia } \\
\text { sophia (L.) } \\
\text { Webb ex } \\
\text { Prantl }\end{array}$ & Jenjar & Brassicaceae & $\mathrm{H}$ & Leaves & $\begin{array}{l}\text { Leaves boiled in water } \\
\text { and then fried in oil with } \\
\text { tomato, onion, and red } \\
\text { chilies }\end{array}$ & $\begin{array}{l}\text { i. Milk } \\
\text { ii. Pulses }\end{array}$ & Mar-Jun & - & 8 & 0.10 & [28] \\
\hline 13 & $\begin{array}{l}\text { Digera } \\
\text { muricata } \\
\text { (L.) Mart. }\end{array}$ & Sur gulay & Amaranthaceae & $\mathrm{H}$ & Leaves & $\begin{array}{l}\text { Boiled leaves are fried in } \\
\text { oil with tomato, onion, } \\
\text { and red chilies }\end{array}$ & $\begin{array}{l}\text { i. Pulses } \\
\text { ii. Potatoes } \\
\text { iii. Rice }\end{array}$ & Jun-Oct & - & 31 & 0.37 & [25] \\
\hline 14 & $\begin{array}{l}\text { Diospyros } \\
\text { lotus L. }\end{array}$ & Tor amlook & Ebenaceae & $\mathrm{T}$ & Fruit & Taken as fruit & & Oct-Jan & + & 34 & 0.40 & {$[26,27]$} \\
\hline 15 & $\begin{array}{l}\text { Ficus carica } \\
\text { L. }\end{array}$ & Inzar & Moraceae & $\mathrm{T}$ & Fruit & Taken as fruit & & Jun-Aug & + & 64 & 0.76 & {$[16,26,27]$} \\
\hline 16 & $\begin{array}{c}\text { Fragaria } \\
\text { nubicola } \\
\text { (Lindl. ex } \\
\text { Hook.f.) } \\
\text { Lacaita }\end{array}$ & $\begin{array}{l}\text { Da zamkay } \\
\text { toot }\end{array}$ & Saxifragaceae & $\mathrm{H}$ & Fruit & Taken as Fruit & $\begin{array}{l}\text { i. Jams } \\
\text { ii. Local ice cream } \\
\text { iii. Custard iv. } \\
\text { Sweets }\end{array}$ & May-Sep & - & 22 & 0.26 & {$[16,27]$} \\
\hline
\end{tabular}


Table 3. Cont.

\begin{tabular}{|c|c|c|c|c|c|c|c|c|c|c|c|c|}
\hline S. No & $\begin{array}{c}\text { Botanical } \\
\text { Name of } \\
\text { WFPs }\end{array}$ & $\begin{array}{l}\text { Local } \\
\text { Name of } \\
\text { WFPs }\end{array}$ & Family & HB & Part Used & $\begin{array}{l}\text { Recipes and Mode of } \\
\text { Utilization in Cuisines }\end{array}$ & $\begin{array}{l}\text { Contribution to } \\
\text { Tribal Food } \\
\text { System } \\
\text { (Use in Other } \\
\text { Cuisines) }\end{array}$ & Coll. Time & Marketing & UR & RFC & $\begin{array}{l}\text { Previously } \\
\text { Reported } \\
\text { in Pakistan for } \\
\text { Food Usages }\end{array}$ \\
\hline 17 & $\begin{array}{l}\text { Indigofera } \\
\text { spp. }\end{array}$ & Gedarghog & $\begin{array}{l}\text { Leguminosae/ } \\
\text { Fabaceae }\end{array}$ & $\mathrm{S}$ & $\begin{array}{c}\text { Aerial } \\
\text { parts }\end{array}$ & $\begin{array}{c}\text { Flowers and leaves are } \\
\text { eaten raw }\end{array}$ & - & Mar-May & - & 3 & 0.04 & \\
\hline 18 & $\begin{array}{l}\text { Lathyrus } \\
\text { aphaca L. }\end{array}$ & Korkaman & $\begin{array}{l}\text { Leguminosae/ } \\
\text { Fabaceae }\end{array}$ & $\mathrm{H}$ & $\begin{array}{c}\text { Aerial } \\
\text { parts }\end{array}$ & $\begin{array}{l}\text { Boiled leaves are fried in } \\
\text { oil with tomato, onion, } \\
\text { and red chilies }\end{array}$ & $\begin{array}{l}\text { i. Pulses } \\
\text { ii. Rice }\end{array}$ & Mar-Jun & - & 17 & 0.20 & {$[23,25]$} \\
\hline 19 & $\begin{array}{l}\text { Malva } \\
\text { neglecta } \\
\text { Wallr. }\end{array}$ & Panderak & Malvaceae & $\mathrm{H}$ & Leaves & $\begin{array}{l}\text { Boiled leaves are fried in } \\
\text { oil with tomato, onion, } \\
\text { and red chilies }\end{array}$ & $\begin{array}{l}\text { Mixed with } \\
\text { i. Rice } \\
\text { ii. Potatoes } \\
\text { iii. Pulses } \\
\text { iv. Yogurt } \\
\text { v. Beef }\end{array}$ & Mar-Nov & + & 28 & 0.33 & {$[22,23]$} \\
\hline 20 & $\begin{array}{l}\text { Marsilea } \\
\text { quadrifolia } \\
\text { L. }\end{array}$ & Chopatra & Marsilleaceae & $\mathrm{H}$ & Leaves & $\begin{array}{l}\text { Boiled leaves are fried in } \\
\text { oil with tomato, onion, } \\
\text { and red chilies }\end{array}$ & $\begin{array}{c}\text { i. Rice } \\
\text { ii. Potatoes } \\
\text { iii. Pulses }\end{array}$ & May-Jul & - & 3 & 0.04 & \\
\hline 21 & $\begin{array}{l}\text { Medicago } \\
\text { polymorpha } \\
\text { L. }\end{array}$ & Speshtaray & Leguminoseae & $\mathrm{H}$ & $\begin{array}{l}\text { Aerial } \\
\text { parts }\end{array}$ & $\begin{array}{l}\text { Boiled leaves are fried in } \\
\text { oil with tomato, onion, } \\
\text { and red chilies }\end{array}$ & $\begin{array}{l}\text { i. Rice } \\
\text { ii. Potatoes } \\
\text { iii. Pulses } \\
\text { iv. Yogurt } \\
\text { v. Beef }\end{array}$ & Mar-Jun & - & 17 & 0.20 & {$[22,23,25]$} \\
\hline 22 & $\begin{array}{l}\text { Mentha } \\
\text { longifolia L. }\end{array}$ & Podina & Lamiaceae & $\mathrm{H}$ & $\begin{array}{l}\text { Aerial } \\
\text { parts }\end{array}$ & $\begin{array}{c}\text { Leaves and young } \\
\text { shoots are eaten as a } \\
\text { salad }\end{array}$ & $\begin{array}{l}\text { i. Flavoring agent } \\
\text { ii. Rice } \\
\text { iii. Custard iv. } \\
\text { Sweets, etc. }\end{array}$ & Mar-Nov & + & 40 & 0.48 & {$[19,22,23,28]$} \\
\hline 23 & $\begin{array}{l}\text { Mentha } \\
\text { royleana } \\
\text { Wall. ex } \\
\text { Benth }\end{array}$ & Enalay & Lamiaceae & $\mathrm{H}$ & $\begin{array}{l}\text { Aerial } \\
\text { parts }\end{array}$ & $\begin{array}{c}\text { Leaves and young } \\
\text { shoots are eaten as a } \\
\text { salad }\end{array}$ & $\begin{array}{l}\text { i. Flavoring agent } \\
\text { ii. Rice } \\
\text { iii. Custard } \\
\text { iv. Sweets, etc. }\end{array}$ & Mar-Nov & $\mathrm{Y}$ & 34 & 0.40 & {$[22,23]$} \\
\hline 24 & $\begin{array}{l}\text { Morus } \\
\text { nigra } \mathrm{L} .\end{array}$ & Tor toot & Moraceae & $\mathrm{T}$ & Fruit & Taken as fruit & $\begin{array}{l}\text { i. Juices } \\
\text { ii. Jams } \\
\text { iii. Syrup }\end{array}$ & Apr-Jul & - & 23 & 0.27 & {$[16,26,27]$} \\
\hline
\end{tabular}


Table 3. Cont.

\begin{tabular}{|c|c|c|c|c|c|c|c|c|c|c|c|c|}
\hline S. No & $\begin{array}{l}\text { Botanical } \\
\text { Name of } \\
\text { WFPs }\end{array}$ & $\begin{array}{l}\text { Local } \\
\text { Name of } \\
\text { WFPs }\end{array}$ & Family & HB & Part Used & $\begin{array}{l}\text { Recipes and Mode of } \\
\text { Utilization in Cuisines }\end{array}$ & $\begin{array}{l}\text { Contribution to } \\
\text { Tribal Food } \\
\text { System } \\
\text { (Use in Other } \\
\text { Cuisines) }\end{array}$ & Coll. Time & Marketing & UR & RFC & $\begin{array}{l}\text { Previously } \\
\text { Reported } \\
\text { in Pakistan for } \\
\text { Food Usages }\end{array}$ \\
\hline 25 & $\begin{array}{l}\text { Morus alba } \\
\text { L. }\end{array}$ & Spin toot & Moraceae & $\mathrm{T}$ & Fruit & Taken as fruit & $\begin{array}{l}\text { i. Juices } \\
\text { ii. Jams }\end{array}$ & Apr-Jul & - & 28 & 0.33 & {$[16,26,27]$} \\
\hline 26 & $\begin{array}{l}\text { Myrsine } \\
\text { africana L. }\end{array}$ & Manrogayah & Primulaceae & $\mathrm{S}$ & Fruit & Taken as fruit & - & Jul-Sep & - & 5 & 0.06 & {$[16,26,27]$} \\
\hline 27 & $\begin{array}{l}\text { Myrtus } \\
\text { communis } \\
\text { L. }\end{array}$ & Myrtaceae & Shrub & $\mathrm{S}$ & Fruit & Taken as fruit & $\begin{array}{l}\text { i. Flavoring } \\
\text { ii. Rice } \\
\text { iii. Curd } \\
\text { iv. Milk } \\
\text { v. Custard } \\
\text { vi. Sweets, etc. }\end{array}$ & Sep-Nov & + & 53 & 0.63 & [53] \\
\hline 28 & $\begin{array}{l}\text { Nannorrhops } \\
\text { ritchieana } \\
\text { (Griff.) } \\
\text { Aitch }\end{array}$ & Mianzarai & Arecaceae & $S$ & Fruit & Taken as fruit & - & Sep-Oct & - & 11 & 0.13 & {$[22,54]$} \\
\hline 29 & $\begin{array}{l}\text { Nasturtium } \\
\text { officinale R. } \\
\text { Br }\end{array}$ & Tarmera & Brassicaceae & $\mathrm{H}$ & Leaves & $\begin{array}{c}\text { Boiled leaves are fried in } \\
\text { butter oil with tomato, } \\
\text { onion, and red chilies }\end{array}$ & $\begin{array}{l}\text { i. Potatoes } \\
\text { ii. Pulses }\end{array}$ & Mar-Nov & - & 47 & 0.56 & {$[22,23,25]$} \\
\hline 30 & $\begin{array}{l}\text { Olea } \\
\text { ferruginea } \\
\text { Wall. ex } \\
\text { Aitch }\end{array}$ & Khona & Oleaceae & $\mathrm{T}$ & Fruit & Taken as fruit & - & Aug-Oct & - & 48 & 0.57 & {$[16,24,26,27]$} \\
\hline 31 & $\begin{array}{c}\text { Opuntia } \\
\text { dillenii } \\
\text { (Ker } \\
\text { Gawl.) } \\
\text { Haw. }\end{array}$ & Tafnra & & $S$ & Fruit & Taken as fruit & - & Sep-Oct & - & 5 & 0.06 & {$[16,27]$} \\
\hline 32 & $\begin{array}{l}\text { Oxalis } \\
\text { corniculata } \\
\text { L. }\end{array}$ & Trewakay & Oxilidaceae & $\mathrm{H}$ & $\begin{array}{c}\text { Aerial } \\
\text { parts }\end{array}$ & $\begin{array}{l}\text { Boiled leaves are fried in } \\
\text { oil with tomato, onion, } \\
\text { and red chilies }\end{array}$ & $\begin{array}{l}\text { i. Rice } \\
\text { ii. Potatoes } \\
\text { iii. Pulses }\end{array}$ & Mar-Dec & - & 44 & 0.52 & {$[22,23,25,27,28]$} \\
\hline
\end{tabular}


Table 3. Cont.

\begin{tabular}{|c|c|c|c|c|c|c|c|c|c|c|c|c|}
\hline S. No & $\begin{array}{l}\text { Botanical } \\
\text { Name of } \\
\text { WFPs }\end{array}$ & $\begin{array}{l}\text { Local } \\
\text { Name of } \\
\text { WFPs }\end{array}$ & Family & HB & Part Used & $\begin{array}{l}\text { Recipes and Mode of } \\
\text { Utilization in Cuisines }\end{array}$ & $\begin{array}{l}\text { Contribution to } \\
\text { Tribal Food } \\
\text { System } \\
\text { (Use in Other } \\
\text { Cuisines) }\end{array}$ & Coll. Time & Marketing & UR & RFC & $\begin{array}{l}\text { Previously } \\
\text { Reported } \\
\text { in Pakistan for } \\
\text { Food Usages }\end{array}$ \\
\hline 33 & $\begin{array}{l}\text { Papaver } \\
\text { rhoeas L. }\end{array}$ & Reday & Papaveraceae & $\mathrm{H}$ & Leaves & $\begin{array}{l}\text { Boiled leaves are fried in } \\
\text { oil with tomato, onion, } \\
\text { and red chilies }\end{array}$ & $\begin{array}{l}\text { i. Rice } \\
\text { ii. Potatoes } \\
\text { iii. Pulses }\end{array}$ & Mar-May & - & 5 & 0.06 & \\
\hline 34 & $\begin{array}{l}\text { Pinus } \\
\text { roxburghii } \\
\text { Sarg. }\end{array}$ & Nakhtar & Pinaceae & $\mathrm{T}$ & Seeds & Seeds are eaten raw & - & Dec-Feb & - & 8 & 0.10 & \\
\hline 35 & $\begin{array}{l}\text { Prunus } \\
\text { armeniaca } \\
\text { L. }\end{array}$ & Zardalo & Rosaceae & $\mathrm{T}$ & Fruit & Taken as fruit & i. Jams & May-Jun & - & 21 & 0.25 & [27] \\
\hline 36 & $\begin{array}{l}\text { Polygonum } \\
\text { aviculare L. }\end{array}$ & Bandakay & Polygonaceae & $\mathrm{H}$ & $\begin{array}{l}\text { Aerial } \\
\text { parts }\end{array}$ & $\begin{array}{l}\text { Boiled leaves are fried in } \\
\text { oil with tomato, onion, } \\
\text { and red chilies }\end{array}$ & $\begin{array}{l}\text { i. Rice } \\
\text { ii. Potatoes } \\
\text { iii. Pulses }\end{array}$ & Mar-Nov & - & 8 & 0.10 & {$[25,28]$} \\
\hline 38 & $\begin{array}{l}\text { Portulaca } \\
\text { quadrifida } \\
\text { L. }\end{array}$ & Warkharay & Portulacaceae & $\mathrm{H}$ & $\begin{array}{l}\text { Aerial } \\
\text { parts }\end{array}$ & $\begin{array}{l}\text { Boiled leaves are fried in } \\
\text { oil with tomato, onion, } \\
\text { and red chilies }\end{array}$ & $\begin{array}{l}\text { i. Beans } \\
\text { ii. Rice } \\
\text { iii. Potatoes } \\
\text { iv. Pulses }\end{array}$ & Jun-Sep & + & 29 & 0.35 & [23-25] \\
\hline 39 & $\begin{array}{l}\text { Punica } \\
\text { granatum } \\
\text { L. }\end{array}$ & Anangoray & Punicaceae & $\mathrm{T}$ & Fruit & Taken as fruit & $\begin{array}{l}\text { i. Juices } \\
\text { ii. Spices } \\
\text { iii. Rice }\end{array}$ & Sep-Oct & - & 27 & 0.32 & {$[24,26,27]$} \\
\hline 40 & $\begin{array}{l}\text { Quercus } \\
\text { baloot Griff }\end{array}$ & Serai & Fagaceae & $\mathrm{T}$ & Fruit & Taken as fruit & $\begin{array}{l}\text { i. Fried and mixed } \\
\text { with corn grains } \\
\text { (rarely used) }\end{array}$ & Dec-Feb & - & 8 & 0.10 & [22] \\
\hline 41 & $\begin{array}{l}\text { Rosa } \\
\text { moschata } \\
\text { Herrm }\end{array}$ & Khwrach & Rosaceae & S & Fruit & Taken as fruit & - & Aug-Oct & - & 4 & 0.05 & {$[16,22,24]$} \\
\hline
\end{tabular}


Table 3. Cont.

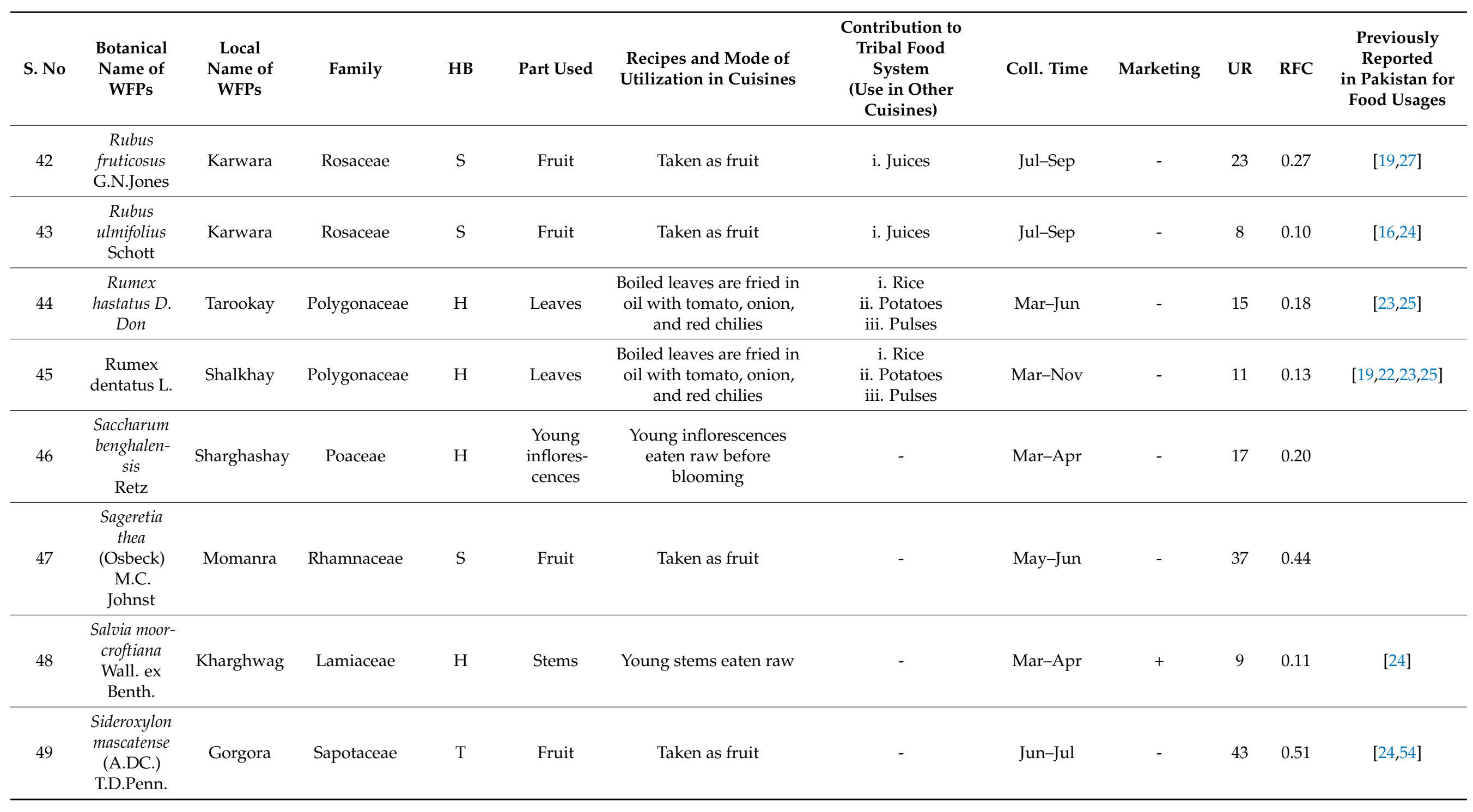


Table 3. Cont.

\begin{tabular}{|c|c|c|c|c|c|c|c|c|c|c|c|c|}
\hline S. No & $\begin{array}{c}\text { Botanical } \\
\text { Name of } \\
\text { WFPs }\end{array}$ & $\begin{array}{l}\text { Local } \\
\text { Name of } \\
\text { WFPs }\end{array}$ & Family & HB & Part Used & $\begin{array}{l}\text { Recipes and Mode of } \\
\text { Utilization in Cuisines }\end{array}$ & $\begin{array}{l}\text { Contribution to } \\
\text { Tribal Food } \\
\text { System } \\
\text { (Use in Other } \\
\text { Cuisines) }\end{array}$ & Coll. Time & Marketing & UR & RFC & $\begin{array}{l}\text { Previously } \\
\text { Reported } \\
\text { in Pakistan for } \\
\text { Food Usages }\end{array}$ \\
\hline 50 & $\begin{array}{c}\text { Silene } \\
\text { conoidea L. }\end{array}$ & Mangotay & Caryophylaceae & $\mathrm{H}$ & Fruit & Taken as fruit & - & Mar-May & - & 22 & 0.26 & {$[19,22,25]$} \\
\hline 51 & $\begin{array}{l}\text { Sisymbrium } \\
\text { irio L. }\end{array}$ & Khob kalan & Brassicaceae & $\mathrm{H}$ & Leaves & Taken as fruit & $\begin{array}{l}\text { i. Rice } \\
\text { ii. Potatoes } \\
\text { iii. Pulses } \\
\text { iv. Milk }\end{array}$ & Mar-Jun & - & 18 & 0.21 & {$[22,28]$} \\
\hline 52 & $\begin{array}{l}\text { Solanum } \\
\text { ameri- } \\
\text { canum } \\
\text { Mill }\end{array}$ & Kachmacho & Solanaceae & $\mathrm{H}$ & $\begin{array}{c}\text { Aerial } \\
\text { parts }\end{array}$ & $\begin{array}{l}\text { Leaves boiled in water } \\
\text { and then fried in oil with } \\
\text { tomato, onion, and red } \\
\text { chilies }\end{array}$ & $\begin{array}{l}\text { i. Rice } \\
\text { ii. Potatoes } \\
\text { iii. Pulses }\end{array}$ & Mar-Sep & - & 7 & 0.08 & {$[23,24,27]$} \\
\hline 53 & $\begin{array}{l}\text { Solanum } \\
\text { villosum } \\
\text { Mill. }\end{array}$ & Kachmacho & Solanaceae & $\mathrm{H}$ & $\begin{array}{l}\text { Aerial } \\
\text { parts }\end{array}$ & $\begin{array}{l}\text { Leaves boiled in water } \\
\text { and then fried in oil with } \\
\text { tomato, onion, and red } \\
\text { chilies }\end{array}$ & $\begin{array}{l}\text { i. Rice } \\
\text { ii. Potatoes } \\
\text { iii. Pulses }\end{array}$ & Mar-Sep & - & 37 & 0.44 & [22] \\
\hline 54 & $\begin{array}{l}\text { Stellaria } \\
\text { media }(\mathrm{L} .) \\
\text { Vill. }\end{array}$ & Khorenakay & Caryophyllaceae & $\mathrm{H}$ & $\begin{array}{c}\text { Aerial } \\
\text { parts }\end{array}$ & $\begin{array}{l}\text { Leaves boiled in water } \\
\text { and then fried in oil with } \\
\text { tomato, onion, and red } \\
\text { chilies }\end{array}$ & $\begin{array}{l}\text { i. Rice } \\
\text { ii. Potatoes } \\
\text { iii. Pulses }\end{array}$ & Mar-May & - & 13 & 0.15 & [25] \\
\hline 55 & $\begin{array}{l}\text { Thymus } \\
\text { linearis } \\
\text { Benth. }\end{array}$ & & Lamiaceae & $\mathrm{H}$ & $\begin{array}{l}\text { Aerial } \\
\text { parts }\end{array}$ & $\begin{array}{l}\text { Aerial parts used in } \\
\text { spices }\end{array}$ & $\begin{array}{c}\text { i Meat } \\
\text { ii Pulses } \\
\text { iii Rice } \\
\text { iii Custard } \\
\text { iv. Spices, etc. }\end{array}$ & May-Oct & - & 23 & 0.27 & [24] \\
\hline 56 & $\begin{array}{l}\text { Trianthema } \\
\text { portulacas- } \\
\text { trum } \\
\quad \text { L. }\end{array}$ & Ghana & Amaranthaceae & $\mathrm{H}$ & Leaves & $\begin{array}{l}\text { Leaves boiled in water } \\
\text { and then fried in oil with } \\
\text { tomato, onion, and red } \\
\text { chilies }\end{array}$ & i. Potatoes & Jun-Sep & - & 13 & 0.15 & \\
\hline
\end{tabular}


Table 3. Cont.

\begin{tabular}{|c|c|c|c|c|c|c|c|c|c|c|c|c|}
\hline S. No & $\begin{array}{l}\text { Botanical } \\
\text { Name of } \\
\text { WFPs }\end{array}$ & $\begin{array}{l}\text { Local } \\
\text { Name of } \\
\text { WFPs }\end{array}$ & Family & HB & Part Used & $\begin{array}{l}\text { Recipes and Mode of } \\
\text { Utilization in Cuisines }\end{array}$ & $\begin{array}{l}\text { Contribution to } \\
\text { Tribal Food } \\
\text { System } \\
\text { (Use in Other } \\
\text { Cuisines) }\end{array}$ & Coll. Time & Marketing & UR & RFC & $\begin{array}{l}\text { Previously } \\
\text { Reported } \\
\text { in Pakistan for } \\
\text { Food Usages }\end{array}$ \\
\hline 57 & $\begin{array}{l}\text { Trifolium } \\
\text { repens L. }\end{array}$ & Shaftal & Leguminosae & $\mathrm{H}$ & $\begin{array}{l}\text { Aerial } \\
\text { parts }\end{array}$ & $\begin{array}{l}\text { Leaves boiled in water } \\
\text { and then fried in oil with } \\
\text { tomato, onion, and red } \\
\text { chilies }\end{array}$ & $\begin{array}{l}\text { i. Rice } \\
\text { ii. Potatoes } \\
\text { iii. Pulses } \\
\text { iv. Yogurt }\end{array}$ & May-Oct & - & 44 & 0.52 & [22] \\
\hline 58 & $\begin{array}{l}\text { Vicia sativa } \\
\text { L. }\end{array}$ & Arwarai & Leguminoseae & $\mathrm{H}$ & Fruit & $\begin{array}{l}\text { Legume is eaten raw or } \\
\text { fried in oil with tomato, } \\
\text { onion, and red chilies }\end{array}$ & $\begin{array}{c}\text { i. Meat } \\
\text { ii. Spinach } \\
\text { iii. Rice } \\
\text { iv. Indian squash }\end{array}$ & Mar-Jun & - & 27 & 0.32 & {$[19,28]$} \\
\hline 59 & $\begin{array}{l}\text { Vitis jacque- } \\
\text { montii R. } \\
\text { Parker }\end{array}$ & Gedarkwar & Vitaceae & $\mathrm{L} / \mathrm{S}$ & Fruits & Taken as fruit & i. Juices & Jul-Aug & + & 13 & 0.15 & {$[16,27]$} \\
\hline 60 & $\begin{array}{l}\text { Zanthoxylum } \\
\text { armatum } \\
\text { DC. }\end{array}$ & Dambara & Rutaceae & $\mathrm{T}$ & Seeds & $\begin{array}{l}\text { Seeds are powdered and } \\
\text { then mixed with curd, } \\
\text { mint leaves, tomato, and } \\
\text { red chilies to make } \\
\text { chutney }\end{array}$ & $\begin{array}{l}\text { i. Curd } \\
\text { ii Pulses } \\
\text { iii Rice } \\
\text { iii Custard } \\
\text { iv. Spices etc. }\end{array}$ & Mar-Jun & - & 37 & 0.44 & {$[16,26,27]$} \\
\hline 61 & $\begin{array}{l}\text { Ziziphus } \\
\text { oxyphylla } \\
\text { Edgew. }\end{array}$ & Enalai & Rhamnaceae & $S$ & Fruit & Taken as fruit & - & Aug-Nov & + & 19 & 0.23 & {$[16,24,26,27]$} \\
\hline 62 & $\begin{array}{l}\text { Ziziphus } \\
\text { jujuba Mill }\end{array}$ & Markhanrai & Rhamnaceae & $\mathrm{T}$ & Fruit & Taken as fruit & - & Aug-Sep & - & 12 & 0.14 & {$[16,24,27]$} \\
\hline 63 & $\begin{array}{l}\text { Ziziphus } \\
\text { nummula- } \\
\text { ria } \\
\text { (Burm.f.) } \\
\text { Wight and } \\
\text { Arn }\end{array}$ & Beera & Rhamnaceae & $\mathrm{T}$ & Fruit & Taken as fruit & - & Oct-Nov & - & 17 & 0.20 & {$[24,26,27,54]$} \\
\hline
\end{tabular}




\subsection{Storage and Uses of WFPs in the Off-Season}

A few of these plant species are available in the market and contribute significantly to the local economy.

Inhabitants of rural areas collect and sell WFPs in the local markets for income generation. Abbasi et al. [25] reported that Dryopteris ramosa, Bauhinia variegata, Chenopodium album, Portulaca quardifida, Nasturtium officinale, Malva parviflora, and Solanum nigrum are sold in the markets of Rawalpindi and Abbottabad, while we did not report the market value for any of these species. According to the findings of Abbas et al. [22], wild vegetable species available in the local markets of Kurram district include Caralluma tuberculata, Mentha spicata, Lepidium draba, Rumex dentatus, Portulaca oleracea, Malva neglecta, Trifolium repens, Stellaria media, and Nasturtium officinale. In the current study, we documented Caralluma tuberculate (Figure 3), Malva neglecta, and Mentha species, which is similar between the two study areas. Rumex dentatus, Malva neglecta, Trifolium repens, Stellaria media, and Nasturtium officinale were very common species and used by tribal communities as vegetables, but we did not observe them in the markets.

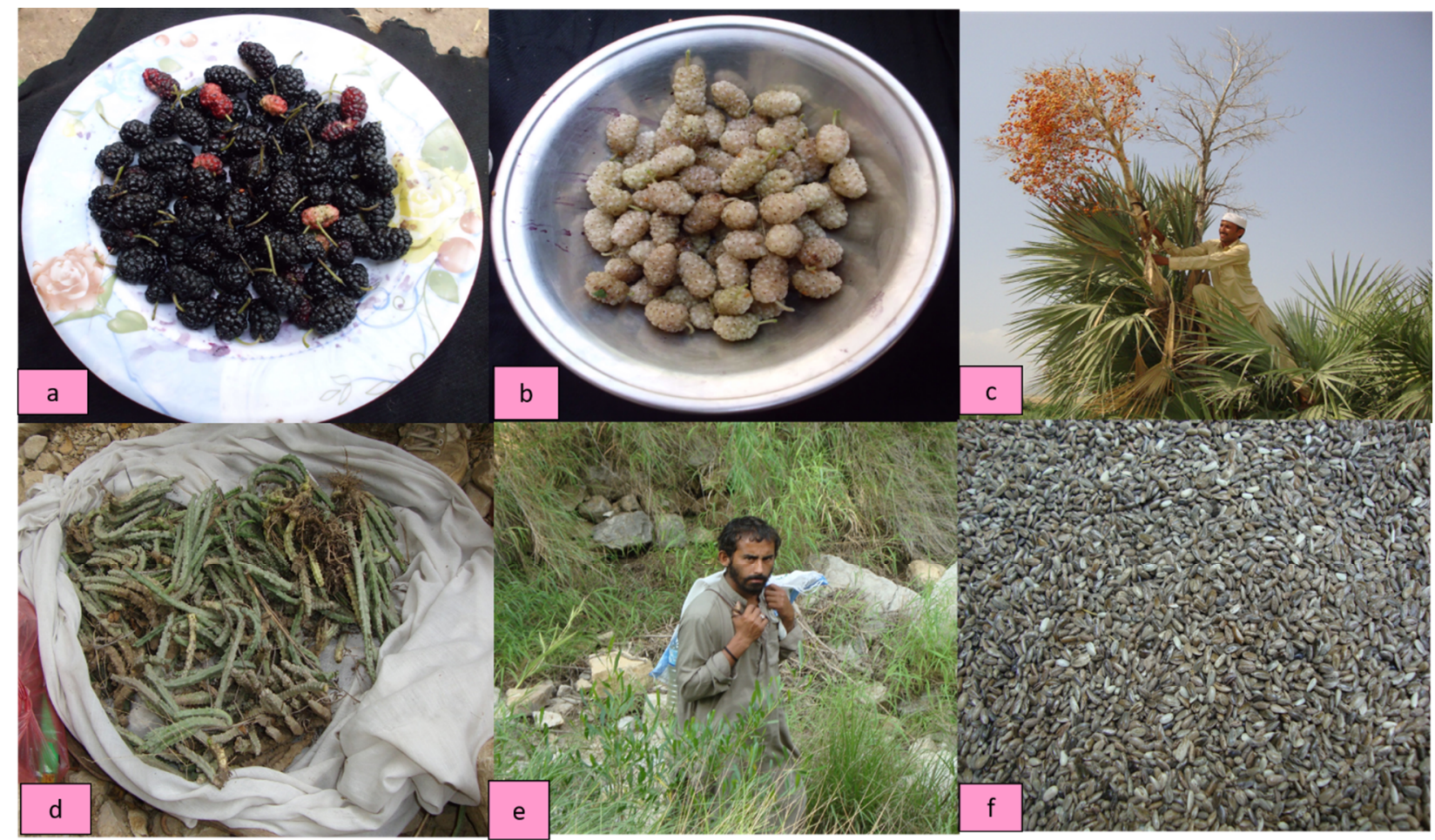

Figure 3. (a) Fruit of Morus nigra, (b) Fruit of Morus alba, (c) a young man collecting fruit of Mazri Palm, (d) Caralluma tuberculata, (e) a young man collecting different wild vegetables, and (f) Seeds of Carthamus oxyacantha.

\section{Discussion}

\subsection{The Reported WFPs Compared to Previous Studies}

We studied the contribution of WFPs to the food system and balancing the nutrition of tribal communities living along the Pakistan-Afghanistan border in the Hindu Kush mountain range. Vegetables were the dominant use category of WFPs across the study region (with 27 different species). Similar studies have also been carried out by other authors on wild vegetables and their nutritional value. For example, Abbas et al. [22] reported 53 wild vegetable species from the Kurram district. Likewise, Abbasi et al. [25] documented 45 wild vegetables from the Lesser Himalayas of Pakistan. In comparison to our study area, the district of Kurram and area of the Lesser Himalayas have a rich diversity of wild vegetable species due to greater rainfall and thus suitability for the growth of WFPs. Aziz et al. [19] reported 21 vegetables used in the remote Yasin and Ishkoman valleys of Gilgit Baltistan, while Ahmad et al., 2019 [23], reported 25 wild 
vegetable species from Northwest Pakistan. The areas of the Pakistani-Afghan border in the Hindu Kush mountains are characterized by dry and harsh climatic conditions which are quite similar to the climatic conditions of the Yasin and Ishkoman valleys and Northwest Pakistan. Therefore, those areas are home to a small number of wild vegetable species. Another study [28] reported 59 wild vegetables from the district of Harnai Baluchistan. The traditional communities of Harnai district use various species that were not mentioned in our study area, such as Boerhavia procumbence, Erodium cicutarium, and Fumaria indica. This disparity in the use of wild vegetable species may be due to the unavailability of food resources or ethnic differences. On this basis, we believe that the use of wild vegetables varies from area to area due to their availability, the climatic conditions, and ethnography.

In this study, fruits were the second most dominant category with 24 species among the recorded WFPs. On the other hand, Abbasi et al. [16] recorded 35 wild fruit species used by the tribal communities of the Lesser Himalayas, and Khan et al., 2015 [27] recorded 47 species of wild fruits from the Swat Valley. The Lesser Himalayas and Swat Valley exhibit a greater diversity of plants and receive more precipitation during the monsoon season compared to the study region. The area of the Hindu Kush including Bajaur, receives very little precipitation during the summer monsoon. These climatic factors distinguish this area from Swat Valley and the Lesser Himalayas in terms of fruit flora. Ahmad and Pieroni [24] studied 31 wild fruit species from the Thakhte-Sulaiman Hills, Northwest Pakistan. The Thakhte-Sulaiman hills are characterized by a dry and harsh climate with mostly bushy and thorny fruit plants such as Berberis calliobotrys, Ziziphus species Cotoneaster microphyllus, Cotoneaster minutus, and Cotoneaster pruinosus. On the other hand Perez-Negron and Casas 2007 [54] documented 11 wild fruit species from the district of Dera Ismail Khan. Dera Ismail Khan is also characterized by very harsh climatic conditions and is considered a hub for Phoenix dactylifera (Dhaki variety) and Nannorrhops ritchieana, especially in the Abdul Khel and Rahmani Khel areas. The Hindu Kush valleys near the Pakistani-Afghan border, including Bajaur, have similar plant taxa such as Sideroxylon mascatense, Nannorrhops ritchieana, and Ziziphus species. In the recent past, ethnobiologists were unwilling to acknowledge the use of Quercus fruits as human food [55], but their consumption is very common in various parts of the world, including Turkey [56,57] and the Iberian Peninsula [55]. Mendez-Baceta et al. [52,55] mentioned that in Gorbeialdea Quercus acorns are considered food for livestock or eaten during times of food scarcity. In the current study, we reported that Quercus acorns were not used as a staple food; however, roasting them is still a hobby in the tribal belt and people come from plain areas to the mountains for acorn collection. Therefore, we suggest that the distribution, diversity, and consumption of wild fruit species vary from region to region depending on their availability, the climatic conditions, nutritional importance, and cultural knowledge.

We also reported various plant species that were used as flavoring agents in sauces and chutneys, i.e., Mentha species. Abbas et al. [22] documented that in the Kurram district Mentha species were used in salads. Aziz et al. [19] reported that, in the Ishkoman and Yaseen valleys of Gilgit Baltistan, Thymus linearis was used in making herbal tea, while in the current study we reported that it was used as a spice. Thus, we believe that variation in the use of WFPs in chutney or sauce making varies from one area to another, perhaps due to ethnography or traditional knowledge. The practice of utilizing raw foods species was also not very common as only six species were reported to be used in raw form. All these plant species were not described as raw food species in other studies previously conducted on the WFPs of Pakistan. Silene conoidea was described by Aziz et al., 2020, Abbas et al., 2020, Abbassi et al., 2013b-[19,22,25] as a cooked vegetable species, while in the current study region it was used as a raw food species rather than as a cooked vegetable.

The use of plants in herbal drinks is an important cultural practice among tribal communities. Aziz et al. [19] mentioned that Carum carvi seeds, Elaeagnus angustifolia bark, and Thymus linearis aerial parts were used as seasonings or herbal drinks. In the current research, we reported that the aerial parts of Thymus linearis were used as an herbal spice, but not as an herbal drink. The other two species, Elaeagnus angustifolia and Carum carvi, 
were not reported in the study area. There is great variation in the climatic conditions and topography of Gilgit Baltistan and areas of the Hindu Kush mountains. Gilgit Baltistan occurs in the Karakoram mountain range, while areas of Pakistani-Afghan border in Bajaur are part of the Hindu Kush mountain range, which suggests that variation in topographic and climatic factors generates variations in floral diversity and traditional uses of plants among local societies.

The tribal belt of Pakistan has a unique food system. Wild food plants are still used in different ways to improve their taste, nutritional value, and health benefits. The local inhabitants prepared many traditional dishes by mixing WFPs with other wild or cultivated vegetables and other foods, i.e., rice, meat, chicken handi, qeema, pulses, Indian squash, potatoes, traditional bread, milk, yogurt, custards, etc. Various other products were also prepared with WFPs, such as juices, syrups, and jams. Carthamus oxycanthus seeds were mixed with brown sugar and heated until caramelized, which is locally called Kaboray (caramel candy).

Guarrera and Savo [12] discussed this tradition in a review article titled "Wild food plants used in traditional vegetable mixtures in Italy". While investigating the wild vegetables of the Lesser Himalayas, Abbasi et al. [25] also mentioned that some vegetable species are cooked in a mixture with other vegetables or in concentrated milk. Abbas et al. [22] documented in their study of the wild vegetables of Kurram district that "all the seasonal wild vegetables are combined intermittently and a particular dish of 7 to 10 species is cooked during festivals (Nowruz) in the Shia community". Therefore, we suggest that the consumption of WFPs, especially that of wild vegetables, mixed with other foods is a long-standing tradition of human societies to improve their taste, nutritional value, and health benefits.

\subsection{Management and Conservation of WFPs}

The territory has a great diversity of wild fruit species, including Ficus carica, Ficus palmata, Morus alba, and Morus nigra, which occur in abundance across the region. Many of these plants are not currently harvested by humans, but there is potential to use them to meet important dietary requirements. These plants can be conserved in their natural habitats and some of them domesticated as well. Very few people dry and store these fruits for consumption in other seasons of the year when these fruits are not available. There is no plan for the management and use of these species. In the present scenario of COVID-19 pandemic-driven situations, people rely on plant-based recipes to manage health care-related issues [57] and such research findings may be of vast attention for people in the rural areas.

\section{Conclusions}

The current research represents the first attempt to study the contribution of WFPs to the food system of the tribal belt of Pakistan at the Pak-Afghan border in the Hindu Kush mountain range. The local inhabitants are economically poor and most of the time utilize local food resources at home. The results showed that WFPs are still collected and consumed in the region. In addition to their nutritional value, 10 species have market value and contribute to the economy of local communities. The uses of Carthamus oxyacantha, Pinus roxburghii seeds, and Marsillea leaves are novel for the gastronomy of Pakistan after comparison with other regions of the country. Myrtus communis, Berberis lyceum, Prunus armeniaca, Nannorrhops ritchieana, Zanthoxylum armatum, and Vitis jacquemontii are the species facing conservation issues due to overexploitation, soil erosion, and climatic changes.

Knowledge related to the consumption of WFPs is decreasing in the younger generations of tribal societies. Therefore, more studies are needed to conserve this important cultural gastronomic heritage of the study region where modernization, urbanization, and industrialization are at their peak. We believe that this study will play a crucial role in the conservation and fostering of the traditional knowledge of WFPs cooking and consumption. 
Author Contributions: A.A. carried out the fieldwork, collected data and prepared the first draft of the manuscript. S.M.K. supervised the project, helped in data analyses, provided the logistic support, read all the revisions and correspond the paper. A.P. contributed to the study design and to draft the MS. A.H. (Amunul Haq) helped during Field Work. Z.U.H. helped in specimens processing. Z.A. contributed in data analyses and preparation of GIS map. S.S. helped in literature review and preparation of paper draft. A.H. (Abeer Hashem), A.-B.F.A.-A., A.A.A. and E.F.A. helped in revising and improving the manuscript and provided partial financial support for the research activity and manuscript processing fee. All authors work parallel to produce the research article in hand shape. All authors have read and agreed to the published version of the manuscript.

Funding: The authors would like to extend their sincere appreciation to the Deanship of Scientific Research at King Saud University for funding this research (RG-1435-014); to the University of Gastronomic Sciences, Pollenzo, Italy for having funded the editing of the paper.

Institutional Review Board Statement: Not applicable.

Informed Consent Statement: Informed consent was obtained from all subjects involved in the study.

Data Availability Statement: Not applicable.

Acknowledgments: The authors would like to extend their sincere appreciation to the Deanship of Scientific Research at King Saud University for funding this research group NO (RG-1435-014). We also highly acknowledge support of the University of Gastronomic Sciences Pollenzo, Italy for their editing services through professional editor. Special thanks also go to the local people of the study area who generously shared their views about WFPs utilization.

Conflicts of Interest: The authors declare no conflict of interest.

\section{References}

1. Abbasi, A.M.; Khan, S.M.; Ahmad, M.; Khan, M.A.; Quave, C.L.; Pieroni, A. Botanical ethnoveterinary therapies in three districts of the Lesser Himalayas of Pakistan. J. Ethnobiol. Ethnomed. 2013, 9, 1-21. [CrossRef] [PubMed]

2. Ju, Y.; Zhuo, J.; Liu, B.; Long, C.J. Eating from the wild: Diversity of wild edible plants used by Tibetans in Shangri-la region, Yunnan, China. J. Ethnobiol. Ethnomed. 2013, 9, 28. [CrossRef]

3. Thakur, D.; Sharma, A.; Uniyal, S.K. Why they eat, what they eat: Patterns of wild edible plants consumption in a tribal area of Western Himalaya. J. Ethnobiol. Ethnomed. 2017, 13, 70. [CrossRef]

4. Guarrera, P.; Savo, V. Perceived health properties of wild and cultivated food plants in local and popular traditions of Italy: A review. J. Ethnopharmacol. 2013, 146, 659-680. [CrossRef]

5. Vitalini, S.; Iriti, M.; Puricelli, C.; Ciuchi, D.; Segale, A.; Fico, G. Traditional knowledge on medicinal and food plants used in Val San Giacomo (Sondrio, Italy)_An alpine ethnobotanical study. J. Ethnopharmacol. 2013, 145, 517-529. [CrossRef]

6. Manduzai, A.K.; Abbasi, A.M.; Khan, S.M.; Abdullah, A.; Prakofjewa, J.; Amini, M.H.; Amjad, M.S.; Cianfaglione, K.; Fontefrancesco, M.F.; Soukand, R. The importance of keeping alive sustainable foraging practices: Wild vegetables and herbs gathered by afghan refugees living in Mansehra District, Pakistan. Sustainability 2021, 13, 1500. [CrossRef]

7. Haq, Z.U.; Khan, S.M.; Iqbal, J.; Razzaq, A.; Iqbal, M. Phyto-medicinal studies in district Lower Dir HinduKush Range Khyberpakhtunkhwa, Pakistan. Pak. J. Weed Sci. Res. 2019, 25, 235.

8. Punchay, K.; Inta, A.; Tiansawat, P.; Balslev, H.; Wangpakapattanawong, P. Traditional knowledge of wild food plants of Thai Karen and Lawa (Thailand). Genet. Resour. Crop. Evol. 2020, 67, 1277-1299. [CrossRef]

9. Shin, T.; Fujikawa, K.; Moe, A.Z.; Uchiyama, H. Traditional knowledge of wild edible plants with special emphasis on medicinal uses in Southern Shan State, Myanmar. J. Ethnobiol. Ethnomed. 2018, 14, 48. [CrossRef]

10. Pieroni, A.; Quave, C.L. Functional foods or food medicines? On the consumption of wild plants among Albanians and southern Italians in Lucania. In Eating and Healing Traditional Food as Medicine; CRC. Press: New York, NY, USA, 2006; pp. 101-129.

11. Pieroni, A.; Sõukand, R.; Amin, H.I.M.; Zahir, H.; Kukk, T. Celebrating multi-religious co-existence in Central Kurdistan: The bio-culturally diverse traditional gathering of wild vegetables among Yazidis, Assyrians, and Muslim Kurds. Hum. Ecol. 2018, 46, 217-227. [CrossRef]

12. Guarrera, P.; Savo, V. Wild food plants used in traditional vegetable mixtures in Italy. J. Ethnopharmacol. 2016, 185, 202-234. [CrossRef]

13. Cornara, L.; La Rocca, A.; Marsili, S.; Mariotti, M. Traditional uses of plants in the Eastern Riviera (Liguria, Italy). J. Ethnopharmacol. 2009, 125, 16-30. [CrossRef] [PubMed]

14. Sundriyal, M.; Sundriyal, R.; Sharma, E.; Purohit, A.N. Wild edibles and other useful plants from the Sikkim Himalaya, India. Oecologia Mont. 1998, 7, 43-54.

15. Kalle, R.; Sõukand, R.; Pieroni, A. Devil is in the details: Use of wild food plants in historical Võromaa and Setomaa, present-day Estonia. Foods 2020, 9, 570. [CrossRef] [PubMed] 
16. Abbasi, A.M.; Khan, M.A.; Khan, N.; Shah, M.H. Ethnobotanical survey of medicinally important wild edible fruits species used by tribal communities of Lesser Himalayas-Pakistan. J. Ethnopharmacol. 2013, 148, 528-536. [CrossRef]

17. Sõukand, R.; Hrynevich, Y.; Vasilyeva, I.; Prakofjewa, J.; Vnukovich, Y.; Paciupa, J.; Hlushko, A.; Knureva, Y.; Litvinava, Y.; Vyskvarka, S.; et al. Multi-functionality of the few: Current and past uses of wild plants for food and healing in Liubań region, Belarus. J. Ethnobiol. Ethnomed. 2017, 13, 10. [CrossRef]

18. Sleet, P. Food Security in Pakistan: Surplus Food is Not Enough to Create a Food Secure Country. F.D.I. 2019. Available online: http:/ / www.futuredirections.org.au/wp-content/uploads / / 04/Food-Security-in-Pakistan-Surplus-Food-is-not-Enoughto-Create-a-Food-Secure-Country.pdf (accessed on 23 December 2020).

19. Aziz, M.A.; Abbasi, A.M.; Ullah, Z.; Pieroni, A. Shared but threatened: The heritage of wild food plant gathering among different linguistic and religious groups in the Ishkoman and Yasin Valleys, North Pakistan. Food 2020, 9, 601. [CrossRef]

20. Sunderland, T.C.H. Food security: Why is biodiversity important? Int. For. Rev. 2011, 13, 265-274. [CrossRef]

21. Shad, M.; Nawaz, H.; Rehman, T.; Ikram, N. Determination of some biochemicals, phytochemicals and antioxidant properties of different parts of Cichorium intybus L.: A comparative study. J. Anim. Plant. Sci. 2013, 23, 1060-1066.

22. Abbas, W.; Hussain, W.; Hussain, W.; Badshah, L.; Hussain, K.; Pieroni, A. Traditional wild vegetables gathered by four religious groups in Kurram District, Khyber Pakhtunkhwa, North-West Pakistan. Genet. Resour. Crop. Ev. 2020, 67, 1521-1536. [CrossRef]

23. Ahmad, K.; Weckerle, C.S.; Nazir, A. Ethnobotanical investigation of wild vegetables used among local communities in northwest Pakistan. Acta Soc. Bot. Pol. 2019, 88, 88. [CrossRef]

24. Ahmad, K.; Pieroni, A. Folk knowledge of wild food plants among the tribal communities of Thakht-e-Sulaiman Hills, North-West Pakistan. J. Ethnobiol. Ethnomed. 2016, 12, 17. [CrossRef]

25. Abbasi, A.M.; Khan, M.A.; Shah, M.H.; Shah, M.M.; Pervez, A.; Ahmad, M. Ethnobotanical appraisal and cultural values of medicinally important wild edible vegetables of Lesser Himalayas-Pakistan. J. Ethnobiol. Ethnomed. 2013, 9, 66. [CrossRef]

26. Abbasi, A.M.; Khan, M.A.; Zafar, M. Ethno-medicinal assessment of some selected wild edible fruits and vegetables of LesserHimalayas, Pakistan. Pak. J. Bot. 2013, 45, 215-222.

27. Khan, M.P.Z.; Ahmad, M.; Zafar, M.; Sultana, S.; Ali, M.I.; Sun, H. Ethnomedicinal uses of edible wild fruits (EWFs) in Swat Valley, Northern Pakistan. J. Ethnopharmacol. 2015, 173, 191-203. [CrossRef]

28. Tareen, N.M.; Saeed-ur-Rehman, M.A.; Shinwari, Z.K.; Bibi, T. Ethnomedicinal utilization of wild edible vegetables in district Harnai of Balochistan Province-Pakistan. Pak. J. Bot. 2016, 48, 1159-1171.

29. Abbasi, A.M.; Shah, M.H.; Khan, M.A. Wild Edible Vegetables of Lesser Himalayas; Springer: Cham, Switzerland, 2015.

30. Tainter, J.A.; MacGregor, D.G. Pashtun Social Structure: Cultural Perceptions and Segmentary Lineage Organization; Macgregor Bates: Cottage Grove, OR, USA, 2011.

31. Lindholm, C. The Islamic Middle East: Tradition and Change; John Wiley \& Sons: Hoboken, NJ, USA, 2008.

32. Khayyam, U.; Ullah, E.I.; Shah, S. Socio-cultural dynamics and their relation with the participatory development in the pashtun tribal society of Pakistan. Int. J. Humanit. Soc. Sci. 2018, 22, 173-184. [CrossRef]

33. Liebl, F.; Schwarz, J.O. Normality of the future: Trend diagnosis for strategic foresight. Futures 2010, 42, 313-327. [CrossRef]

34. Ullah, A. Governance reforms in federally administered tribal areas (fata) of Pakistan: The past and present. J. Political. Stud. 2015, 22, 215.

35. Fair, C.C.; Howenstein, N.; Thier, J.A. Troubles on the Pakistan-Afghanistan Border; United States Institute of Peace: Washington, DC, USA, 2006.

36. Jehan, S.; Khan, S.; Khattak, S.A.; Muhammad, S.; Rashid, A.; Muhammad, N. Hydrochemical properties of drinking water and their sources apportionment of pollution in Bajaur agency, Pakistan. Measurement 2019, 139, 249-257. [CrossRef]

37. Aziz, M.A.; Adnan, M.; Khan, A.H.; Sufyan, M.; Khan, S.N. Cross-cultural analysis of medicinal plants commonly used in ethnoveterinary practices at South Waziristan Agency and Bajaur Agency, federally administrated tribal areas (FATA), Pakistan. J. thnopharmacol. 2018, 210, 443-468. [CrossRef]

38. Abdullah, S.M.K.; Kashif, R.A.; Haq, Z.U.; Ahmad, Z.; Haq, A.U.; Haq, M.A. Ethnobotanical appraisal of medicinal plants from Bajaur; A remote area of the Khyber Pakhtunkhwa province of Pakistan. In Ethnobiology of Mountain Communities in Asia; Springer: Cham, Switzerland, 2021; pp. 277-293.

39. Ul Haq, A.Z.; Khan, S.M. The indispensable bond between Mazri Palm (Nannorrhops ritchiana) and the Indian Porcupine (Hystrix indica) leads them towards extinction! Biodivers. Conserv. 2019, 28, 3387-3388.

40. Sher, K. Utmankhel and Utmankheli; Danyal Publishers: Lahore, Pakistan, 2019; Volume 1, p. 110.

41. Dolina, K.; Luczaj, L. Wild food plants used on the Dubrovnik coast (south-eastern Croatia). J. Ethnobiol. Ethnomed. 2014, 83, 175-181. [CrossRef]

42. Tongco, M.D.C. Purposive sampling as a tool for informant selection. Ethnobot. Res. App. 2007, 5, 147-158. [CrossRef]

43. Khan, S.M.; Page, S.; Ahmad, H.; Shaheen, H.; Ullah, Z.; Ahmad, M.; Harper, D.M. Medicinal flora and ethnoecological knowledge in the Naran Valley, Western Himalaya, Pakistan. J. Ethnobiol. Ethnomed. 2013, 9, 4. [CrossRef]

44. Pieroni, A. Traditional uses of wild food plants, medicinal plants, and domestic remedies in Albanian, Aromanian and Macedonian villages in South-Eastern Albania. J. Herb. Med. 2017, 9, 81-90. [CrossRef]

45. Ali, S.I.; Qaiser, M. A phytogeographical analysis of the phanerogams of Pakistan and Kashmir. Pak. R. Soc. Edinb. A 1986, 89, 89-101. [CrossRef]

46. Rehman, M.U. Wild Plants of Swat Valley; Springer Science \& Business Media: Cham, Switzerland, 2019 ; Volume 2. 
47. Kolosova, V.; Belichenko, O.; Rodionova, A.; Melnikov, D.; Sõukand, R. Foraging in Boreal Forest: Wild food plants of the republic of Karelia, NW Russia. Food 2020, 9, 1015. [CrossRef]

48. Abdullah, K.; Shujaul, M.; Pieroni, A.; Haq, Z.; Ahmad, Z. Mazri (Nannorrhops ritchiana (Griff) Aitch.): A remarkable source of manufacturing traditional handicrafts, goods and utensils in Pakistan. J. Ethnobiol. Ethnomed. 2020, 16, 1-13. [CrossRef]

49. Aziz, M.A.; Khan, A.H.; Adnan, M.; Ullah, H. Traditional uses of medicinal plants used by Indigenous communities for veterinary practices at Bajaur Agency, Pakistan. J. Ethnobiol. Ethnomed. 2018, 14, 11. [CrossRef] [PubMed]

50. Feyssa, D.H.; Njoka, J.T.; Asfaw, Z. Seasonal availability and consumption of wild edible plants in semiarid Ethiopia: Implications to food security and climate change adaptation. J. Hortic. For. 2011, 3, 138-149.

51. Menendez-Baceta, G.; Aceituno-Mata, L.; Tardío, J.; Reyes-García, V.; Pardo-de-Santayana, M. Wild edible plants traditionally gathered in Gorbeialdea (Biscay, Basque Country). Genet. Resour. Crop Evol. 2012, 59, 1329-1347. [CrossRef]

52. Ali, K.; Ullah, F.; Khan, N.; Rahman, I.U.; Ullah, S.; Khan, W.; Ali, M.; Uddin, N.; Nisar, M. Ethnobotanical and ecological study of Myrtus communis (L.) in Bajaur agency (FATA) Khyber-Pakhtunkhwa, Pakistan. J. Biodivers. Environ. Sci. 2017, 11, 152-164.

53. Marwat, S.K.; Usman, K.; Khakwani, A.A.; Ghulam, S.; Anwar, N.; Sadiq, M.; Khan, S.J. Medico-ethnobotanical studies of edible wild fruit plants species from the flora of north western Pakistan (DI Khan district). Med. Plan. Res. 2011, 5, 3679-3686.

54. Pérez-Negrón, E.; Casas, A. Use, extraction rates and spatial availability of plant resources in the Tehuacán-Cuicatlán Valley, Mexico: The case of Santiago Quiotepec, Oaxaca. J. Arid Environ. 2007, 70, 356-379. [CrossRef]

55. Mason, S.; Nesbitt, M. Acorns as food in southeast Turkey: Implications for prehistoric subsistence in Southwest Asia. In From Foragers to Farmers: Papers in Honour of Gordon C. Hillman; Oxbow Books: Oxford, UK, 2009; pp. 71-85.

56. Yeşil, Y.; İnal, İ. Traditional knowledge of wild edible plants in Hasankeyf (Batman Province, Turkey). Acta Soc. Bot. Pol. 2019, 88, 3633. [CrossRef]

57. Pieroni, A.; Vandebroek, I.; Prakofjewa, J.; Bussmann, R.W.; Paniagua-Zambrana, N.Y.; Maroyi, A.; Torri, L.; Zocchi, D.M.; Dam, A.T.K.; Khan, S.M.; et al. Taming the pandemic? The importance of homemade plant-based foods and beverages as community responses to COVID-19. J. Ethnobiol. Ethnomed. 2020, 16, 1-9. [CrossRef] [PubMed] 